Max-Planck-Institut für demografische Forschung

Max Planck Institute for Demographic Research

Doberaner Strasse 114 - D-18057 Rostock · GERMANY

Tel +49 (0) 3812081 - 0; Fax +49 (0) 3812081 - 202;

http://www.demogr.mpg.de

MPIDR WORKING PAPER WP 2001-010

APRIL 2001

Life-table representations of family

dynamics in Sweden and Hungary:

initiation of a project of descriptions of

demographic behavior

Gunnar Andersson (andersson@ demogr.mpg.de)

Dimiter Philipov (philipov@demogr.mpg.de)

This working paper has been approved for release by: Jan M. Hoem (hoem@ demogr.mpg.de)

Head of the Laboratory of Contemporary European Fertility and Family Dynamics.

(C) Copyright is held by the authors.

Working papers of the Max Planck Institute for Demographic Research receive only limited review. Views or opinions expressed in working papers are attributable to the authors and do not necessarily reflect those of the Institute. 


\title{
Life-table representations of family dynamics in Sweden and Hungary: initiation of a project of descriptions of demographic behavior
}

\author{
by Gunnar Andersson \\ and Dimiter Philipov
}

\begin{abstract}
In this paper, we present a system of descriptions of family-demographic behavior in developed countries. We use life-table techniques in order to describe the experiences of men, women, and children in processes related to family formation and family dissolution. We develop a large number of descriptive measures and apply them to survey data from Sweden and Hungary. The paper demonstrates the potential of our descriptive system for further crosscountry comparisons of the demographic behavior in European countries.
\end{abstract}




\section{CREATIVE DESCRIPTION}

The purpose of this paper is to introduce an extensive number of life tables that give information on various aspects of family demographic behavior in Sweden and Hungary by describing different aspects of life trajectories of people in these countries. It is our hope that a massive tabulation like that presented here will provide us with a better picture of issues such as family formation and family dissolution in these countries and that it can serve as a basis for a more in-depth cross-country comparison. In addition, we believe that our set of descriptive devices can serve as a raw model for the production of further descriptions of the demographic behavior in other developed countries. If this is done, we will be provided with a large amount of detailed background data that can be used for more specific studies of different aspects of family demography - from the point of view of men, women, and children.

We are convinced that there is still room for more and better description of the actual state of family dynamics and life courses of individuals in our part of the world. Indeed, we think it is important to have a fairly good overall picture of the state of affairs in family demography before one starts to look for explanations for various types of behavior and before one turns to more sophisticated means of analyses. It is necessary to know exactly what there is to explain before one tries to explain it and we hope that our tabulations will provide meaningful information on existing patterns of family behavior in Sweden and Hungary. Some related descriptions of family-demographic behavior in developed countries have been presented elsewhere. Inspiring examples are, for example, given by Kiernan (1999a,b, 2000) who presents a large number of descriptive tabulations on cohabitation and extra-marital childbearing in a wide number of Western European countries and by Bumpass and Lu (2000) who present a description of patterns in cohabitation in the United States. Nevertheless, we believe that the richness of our tabulations and our consistent focus on patterns in life trajectories will make them a very useful source for further creative descriptions of contemporary demographic behavior.

The purpose of this project has been to derive a suitable set of descriptive measures that can be used for various types of cross-country comparisons. Our measures describe different types of family experiences from the point of view of men, women, and children. We have applied our measures to data stemming from the latest Fertility and Family Surveys (FFS) conducted in Sweden and Hungary. In our presentation, we give complete tabulations for these countries in a readable manner. This gives a good overview of our tabulations and demonstrates the potential for further cross-country comparisons. We are convinced that our paper will inspire to the application of our system of description also to data from other European countries.

Most of our descriptive measures are based on life-table techniques and we present three broad groups of tabulations. First, we present a number of measures on various aspects of family formation of men and women. These show the cumulative percent of men and women who have experienced a specific demographic event by single-year ages from their $15^{\text {th }}$ to their $40^{\text {th }}$ birthday. In principle, we would like to extend these tabulations beyond the age of 40 but since most family related surveys are directed only to respondents at "reproductive ages" we have to stop our calculations at that age. Secondly, we present a number of measures on various experiences of men and women in unions, by duration of union. Here we use the union as our unit of observation and we pool the information on unions as reported by women and men. We report various types of experiences in different types of unions so that we, for example, report the cumulative percent of consensual unions who are being dissolved or are being transformed into a marriage by single-year durations up to the $15^{\text {th }}$ (or $20^{\text {th }}$ ) birthday of 
the union. Thirdly, we present various life-table measures on children's experiences of family formation and family dissolution. These measures are all calculated from the information given by their mothers' reports of union events and they are presented by single-year ages of the child, from birth to the $15^{\text {th }}$ birthday. The various life-table measures are finally summarized in a few tables and figures that report the fractions of total time that men, women, and children spend in various family types during their reproductive ages or during childhood.

Our life-table measures are all based on the notion of a synthetic cohort corresponding to the calendar-year period immediately before the FFS survey of interest. While a calculation of life tables for a real birth cohort of men, women and children, or a real marriage cohort, is a straightforward matter, it requires that one can follow the cohort of interest up to the highest age limit of the tabulation, for example up to age 40. In our case, we prefer to be able to say something about the demographic behavior during a specific calendar-year period. For that purpose, we construct a life table from estimated transition rates calculated from exits from the population under risk of experiencing a particular event, at various ages, during the specific calendar-year period of interest. Such a procedure allows us to estimate a synthetic life table for that period with information on the demographic pattern that would arise if the calculated age-specific transition rates prevail during a generation or so.

For Hungary, we use the six-year period immediately prior to the survey in 1992/1993 as the basis for our synthetic cohort so our tabulations describe the demographic situation in 1986/1987--1992/1993, i.e., in the years just before and after the political and economical turnaround in Hungary. The FFS of Sweden was targeted at the same time, in 1992/1993, on a limited number of single-year birth cohorts of men and women. Nevertheless, we have here again used the idea of a synthetic cohort in our presentation in order to derive measures that are useful in a cross-country comparison and to derive information on the demographic behavior during a calendar period. However, to cover all ages of interest for family-formation events of Swedish men and women, we have had to use data corresponding to the calendar period 15 years prior to survey. (The youngest male cohort at interview was of age 29 and we need to follow their family-formation experiences from age 14, which calls for a retrospective study period of 15 years.) This means that our life tables of family formation of adult Swedes describe the demographic situation in 1977/1978--1992/1993, a fact that has to be remembered when comparisons are made with the tabulations for Hungary. Several changes in behavior in Sweden may have occurred during this more extended study period. When our unit of observation is unions of Swedes, we can use a shorter period for our synthetic-cohort measures, better corresponding to that of Hungary, and when we describe the family-transformation experiences of children in Sweden, we use the six-year period before the survey as we do for Hungary.

In our tables, we present measures such as "the cumulative percent of men and women who have ever experienced the event of entering a first union", by single-year ages attained from the situation at the $15^{\text {th }}$ birthday to the $40^{\text {th }}$ birthday. In the tabulations, we also present a number of mean and percentile values in order to derive some summary information from our life tables. For example, we present values of mean ages of transition for those men and women who actually experience the event of interest before the upper age limit of 40 years. (For children the upper age limit is instead 15 years while we follow unions until their $15^{\text {th }}$ or $20^{\text {th }}$ birthday.) We may refer to these mean values as conditional means in that they are conditional on the occurrence of an event. We also present the first exact age where at least $10,25,50$, and 75 percent of the study population first have experienced the event under study, i.e., the ages of the first percentile, the first quartile, the median, and the third quartile. 
When we follow unions (and also when we follow children) and report on events such as union dissolution by duration of time since union formation (or, in the case of children, by age of child), we will report yet another type of mean value. This value is calculated at the upper age limit of the life table as the mean duration of all episodes, regardless of whether they are censored at that time horizon or whether individuals have experienced the event under study before that age. These truncated mean values give information on the average amount of time that will be spent in a certain family status during the 15(20) years following union formation (or the 15 years following birth).

\section{DATA}

For Hungary, we have used the data given in the standard recode files of the FFS provided to us by the Population Activities Unit in Geneva. This data had to be cleaned in various ways before we could use them so that, for example, respondents with incomplete information or illogical sequences of events have been removed from the study population. For Sweden, we have used a version of the FFS that already has been cleaned with a fairly high level of ambition, also comprising imputations of missing pieces of information, at the Stockholm University Demography Unit and at Statistics Sweden.

For Sweden, we have excluded those respondents who had immigrated to that country at reproductive ages, i.e., after age 15 . In our study of children's experiences of various family events, we have only included those children who were born in Sweden. In the case of migration during the age segments that we want to study, we expect to find some interdependence between migration and family-formation and we don't want to deal with such issues here. For Hungary, as for other countries of the standard recode files, we have no information on any country of birth of the survey respondents. This means that possible immigrants are included in the investigation and that we cannot distinguish between demographic events that occurred in the country of origin and in the country of destination, since we neither have any information on actual dates of immigration. This is a less desirable feature of the data but, in the case of Hungary, not a source of major concern since the level of immigration to Hungary so far has been very low.

The following numbers of male and female respondents, and children of female respondents, have been used as the basis four our calculations.

Swedish men Swedish women Hungarian men Hungarian women

\begin{tabular}{|c|c|c|c|c|}
\hline $\begin{array}{l}\text { Number of } \\
\text { adults: }\end{array}$ & 1495 & 2986 & 1899 & 3498 \\
\hline $\begin{array}{l}\text { Number of } \\
\text { children: }\end{array}$ & & 4638 & & 490 \\
\hline
\end{tabular}

As stressed by Lesthaeghe (2000), we need to make an additional warning for the lack of data validation in this project - as in most other projects that use standardized FFS data. In the case of Hungary, we have not been able to perform a very thorough cleaning of the data at hand and we have neither been able to make any deeper investigation of, for example, sampling 
procedures and how they have differed between the countries. We have just used the data provided to us but have removed a number of evident cases of inconsistencies in it.

We now turn to the presentation of our life-table estimates. As mentioned above, we have calculated our life tables from estimated probabilities of exit from the study population, due to a specific event under study, or of surviving in the original state. If the number of persons under risk of experiencing the specific event decreases to a level of less than 15 individuals (at some higher duration or age segment), we will freeze our life-table estimation at that stage. We will then be unable to present any further figures for durations above that time horizon. This can, for example, occur when the number of unions of a specific type, like consensual unions in Hungary, is too small for an extended investigation of their destinies. It can also occur when practically the whole study population experience a particular event already at a relatively early stage, like in the process of leaving the parental home in Sweden.

We will discuss various aspects of our data and describe what our estimates stand for as our presentation evolves. In addition, we will make some limited comments on substantive issues, i.e., on the demographic patterns that we observe in our tabulations. Before we start, we also want to make a short comment on the effects of the Swedish marriage boom in 1989 on estimated patterns of family transformations for Sweden. Since an unusually large number of marriages were formed in that year (see Hoem, 1991) and since these marriages occurred in the period for which we estimate our synthetic-cohort measures, these measures will be strongly influenced by that specific event. We would get a different picture of the marriageformation patterns in Sweden if this event had not occurred. Our estimates of union-disruption patterns are also affected by this event since divorce risks of the marriage cohort of 1989 generally have been lower than for other marriage cohorts (Andersson, 1998). In the case of Hungary, there have as well been a number of changes in demographic behavior during the study period we use, that will not be accounted for explicitly by our tabulations. These changes, however, have occurred more gradually over time so that we in any case are able to derive meaningful information on patterns of demographic behavior during this transitional period. As an initial check, we have performed separate calculations for the first and the second half of the study period we use (not shown here) in order to be sure that the basic patterns that we observe have not changed too much over time. 


\section{A. MEASURES OF FAMILY FORMATION OF MEN AND WOMEN}

Our measures of family formation are all cumulative proportions of men/women who have ever experienced a particular family-formation event at the exact ages 15-40 years. In our tables, we present such proportions at every even age from age 16 to age 30 , with additional information given for ages 25,35 , and 40 .

We begin with a presentation of patterns of leaving the parental home in Sweden and Hungary (Table 1). The two countries contrast each other very well with a pattern for Sweden where home leaving occur very rapidly around the age of 20 , and where practically everybody has left their home at an age of 25-26 years, and the pattern for Hungary where home leaving takes place at a much slower rate and where substantial fractions of young people never leave the parental home at all. In the latter case, family formation may occur anyway but then within the original home.

\begin{tabular}{|c|c|c|c|c|}
\hline Swedish & men & Swedish women & Hungarian men & Hungarian women \\
\hline 16 & 4 & 6 & 1 & 2 \\
\hline 18 & 19 & 29 & 2 & 7 \\
\hline 20 & 46 & 73 & 7 & 25 \\
\hline 22 & 78 & 93 & 19 & 46 \\
\hline 24 & 91 & 98 & 35 & 63 \\
\hline 25 & 94 & 99 & 43 & 69 \\
\hline 26 & 96 & 99 & 49 & 72 \\
\hline 28 & 98 & -- & 58 & 77 \\
\hline 30 & 98 & -- & 65 & 80 \\
\hline 35 & -- & -- & 74 & 83 \\
\hline 40 & -- & -- & 75 & 84 \\
\hline $\begin{array}{l}\text { mean age: } \\
\text { (at transition) }\end{array}$ & 20 & 19 & 25 & 22 \\
\hline 1st decile at age: & 17 & 17 & 21 & 19 \\
\hline 1st quartile: & 19 & 18 & 23 & 20 \\
\hline median at age: & 21 & 19 & 27 & 23 \\
\hline 3rd quartile at: & 22 & 21 & 39 & 27 \\
\hline
\end{tabular}

We proceed with a presentation of measures on the (i) cumulative percent ever starting a first union as a cohabitation, by single-year age, and (ii) the cumulative percent ever starting a first union as a marriage, by age. First, we present a single-decrement life table for each of the two events (Tables 2 and 3) where we censor at the occurrence of the competing event. The separate tables thus describe the family-formation intensities by just one way of entering a union for people who have never yet lived in a union. Again, we discover huge differences between the risk patterns for Sweden and for Hungary. The propensity to enter a first union as a cohabitation is very strong in Sweden while the propensity there to enter it as a marriage is quite unimportant. For Hungary, there is instead a much stronger tendency for never-partnered people to enter into a marriage than to a consensual union. 
Table 2: Cumulative percent ever starting a first union as a cohabitation, single-decrement life-table method with censoring at direct marriage

$\begin{array}{ccccc}\text { age } & \text { Swedish men } & \text { Swedish women } & \text { Hungarian men } & \text { Hungarian women } \\ 16 & 0 & 2 & 0 & 1 \\ 18 & 3 & 12 & 1 & 6 \\ 20 & 16 & 38 & 5 & 14 \\ 22 & 40 & 62 & 12 & 24 \\ 24 & 60 & 76 & 20 & 34 \\ 25 & 67 & 81 & 25 & 38 \\ 26 & 72 & 84 & 30 & 42 \\ 28 & 80 & 88 & 37 & 51 \\ 30 & 84 & 91 & 39 & 55 \\ 35 & 90 & 94 & 48 & 62 \\ 40 & 92 & 95 & 53 & 25 \\ \text { mean age: } & 23 & 22 & 26 & \\ \text { (at transition) } & & & & 20 \\ \text { 1st decile: } & 20 & 18 & 22 & 23 \\ \text { 1st quartile: } & 21 & 20 & 25 & 30 \\ \text { median: } & 23 & 21 & 37 & -\end{array}$

Table 3: Cumulative percent ever starting a first union as a marriage, single-decrement life-table method with censoring at entry into cohabitation

\begin{tabular}{|c|c|c|c|c|}
\hline age & men & Swedish women & Hungarian men & Hungarian women \\
\hline 16 & 0 & 0 & 0 & 0 \\
\hline 18 & 0 & 0 & 0 & 5 \\
\hline 20 & 0 & 1 & 3 & 24 \\
\hline 22 & 1 & 2 & 12 & 46 \\
\hline 24 & 2 & 4 & 29 & 65 \\
\hline 25 & 3 & 4 & 37 & 71 \\
\hline 26 & 4 & 5 & 44 & 75 \\
\hline 28 & 7 & 6 & 55 & 78 \\
\hline 30 & 8 & 9 & 61 & 79 \\
\hline 35 & 14 & 12 & 67 & 82 \\
\hline 40 & 18 & 15 & 68 & 84 \\
\hline $\begin{array}{l}\text { mean age: } \\
\text { (at transition) }\end{array}$ & 30 & 29 & 25 & 22 \\
\hline 1st decile: & 32 & 31 & 22 & 19 \\
\hline 1st quartile: & -- & -- & 24 & 21 \\
\hline median: & -- & -- & 27 & 23 \\
\hline 3rd quartile: & -- & -- & -- & 26 \\
\hline
\end{tabular}

We follow up with a presentation of the patterns in entering a first union as they appear when we describe them with a competing-risks life-table method. This method gives a good description of the actual fractions of people who eventually end up either in a marriage or in a consensual union immediately after they have entered their first union. One advantage with this description is that the cumulative percentages of the two tabulations now add up to the cumulative percent of people who have ever entered a union at all. We thus present the fractions of men and women who had entered their first union either by a cohabitation (Table 
4) or by a direct marriage (Table 5) at each actual age, followed by a tabulation of the sum of the two, i.e., the fractions who had ever entered any union at all (Table 6).

Table 4: Cumulative percent ever starting a first union as a cohabitation, competing-risks life-table method with direct marriage as competing event

$\begin{array}{ccccc}\text { age } & \text { Swedish men } & \text { Swedish women } & \text { Hungarian men } & \text { Hungari } \\ 16 & 0 & 2 & 0 & 1 \\ 18 & 3 & 12 & 1 & 5 \\ 20 & 16 & 38 & 4 & 12 \\ 22 & 40 & 62 & 11 & 19 \\ 24 & 59 & 76 & 17 & 24 \\ 25 & 66 & 80 & 21 & 25 \\ 26 & 72 & 83 & 24 & 26 \\ 28 & 78 & 87 & 27 & 27 \\ 30 & 83 & 90 & 28 & 29 \\ 35 & 88 & 92 & 31 & 30 \\ 40 & 89 & 93 & 33 & 22 \\ \text { mean age: } & 23 & 21 & 25 & \\ \text { (at transition) } & & & & 20 \\ \text { 1st decile: } & 20 & 18 & 22 & 25 \\ \text { 1st quartile: } & 21 & 20 & 27 & - \\ \text { median: } & 23 & 21 & -- & - \\ \text { 3rd quartile: } & 27 & & & \end{array}$

Table 5: Cumulative percent ever starting a first union as a marriage, competing-risks life-table method with entry into cohabitation as competing event

age Swedish men Swedish women Hungarian men Hungarian women

$\begin{array}{lrrrr}16 & 0 & 0 & 0 & 0 \\ 18 & 0 & 0 & 0 & 4 \\ 20 & 0 & 0 & 3 & 22 \\ 22 & 1 & 1 & 11 & 40 \\ 24 & 1 & 2 & 25 & 53 \\ 25 & 1 & 2 & 32 & 57 \\ 26 & 2 & 2 & 37 & 59 \\ 28 & 3 & 2 & 44 & 62 \\ 30 & 3 & 2 & 48 & 63 \\ 35 & 3 & 3 & 51 & 64 \\ 40 & 4 & 3 & 52 & 22 \\ & & & & \\ \text { an age: } & 27 & 25 & 25 & 19 \\ t \text { transition } & & & & 21 \\ & -- & -- & 22 & 24 \\ \text { t decile: } & -- & -- & 32 & -\end{array}$




\begin{tabular}{|c|c|c|c|c|}
\hline Swedish & men & Swedish women & Hungarian men & Hungarian women \\
\hline 16 & 0 & 2 & 0 & 1 \\
\hline 18 & 3 & $1 \overline{2}$ & 2 & 10 \\
\hline 20 & 16 & 39 & 8 & 34 \\
\hline 22 & 41 & 63 & 22 & 59 \\
\hline 24 & 61 & 77 & 43 & 77 \\
\hline 25 & 68 & 81 & 53 & 82 \\
\hline 26 & 73 & 85 & 60 & 85 \\
\hline 28 & 81 & 89 & 71 & 88 \\
\hline 30 & 86 & 92 & 76 & 90 \\
\hline 35 & 91 & 94 & 82 & 92 \\
\hline 40 & 93 & 96 & 85 & 94 \\
\hline $\begin{array}{l}\text { mean age: } \\
\text { (at transition) }\end{array}$ & 23 & 22 & 25 & 22 \\
\hline 1st decile: & 20 & 18 & 21 & 18 \\
\hline 1st quartile: & 21 & 20 & 23 & 20 \\
\hline median: & 23 & 21 & 25 & 22 \\
\hline 3rd quartile: & 27 & 24 & 30 & 24 \\
\hline
\end{tabular}

From the tables above we can see that people in Sweden enter their first union at a faster pace than people in Hungary (which also holds for women as compared to men) and that a higher fraction of people in Sweden will have an experience of a union formation. This difference between countries is much more pronounced for men than it is for women. We can also see that practically all people in Sweden actually start their first union as a cohabitation while the majority of Hungarians do so by a direct marriage. In these tabulations it would have been nice to be able to present results also for ages above the upper limit of 40 years since, at least for men in Hungary, union formation might proceed above that age.

Our next life tables give information about the cumulative percentages who will ever enter a marriage (Table 7), regardless of whether this occurs as an entry to a direct marriage, as a transformation of a first consensual union into a marriage, or as a marriage at any higher union order.

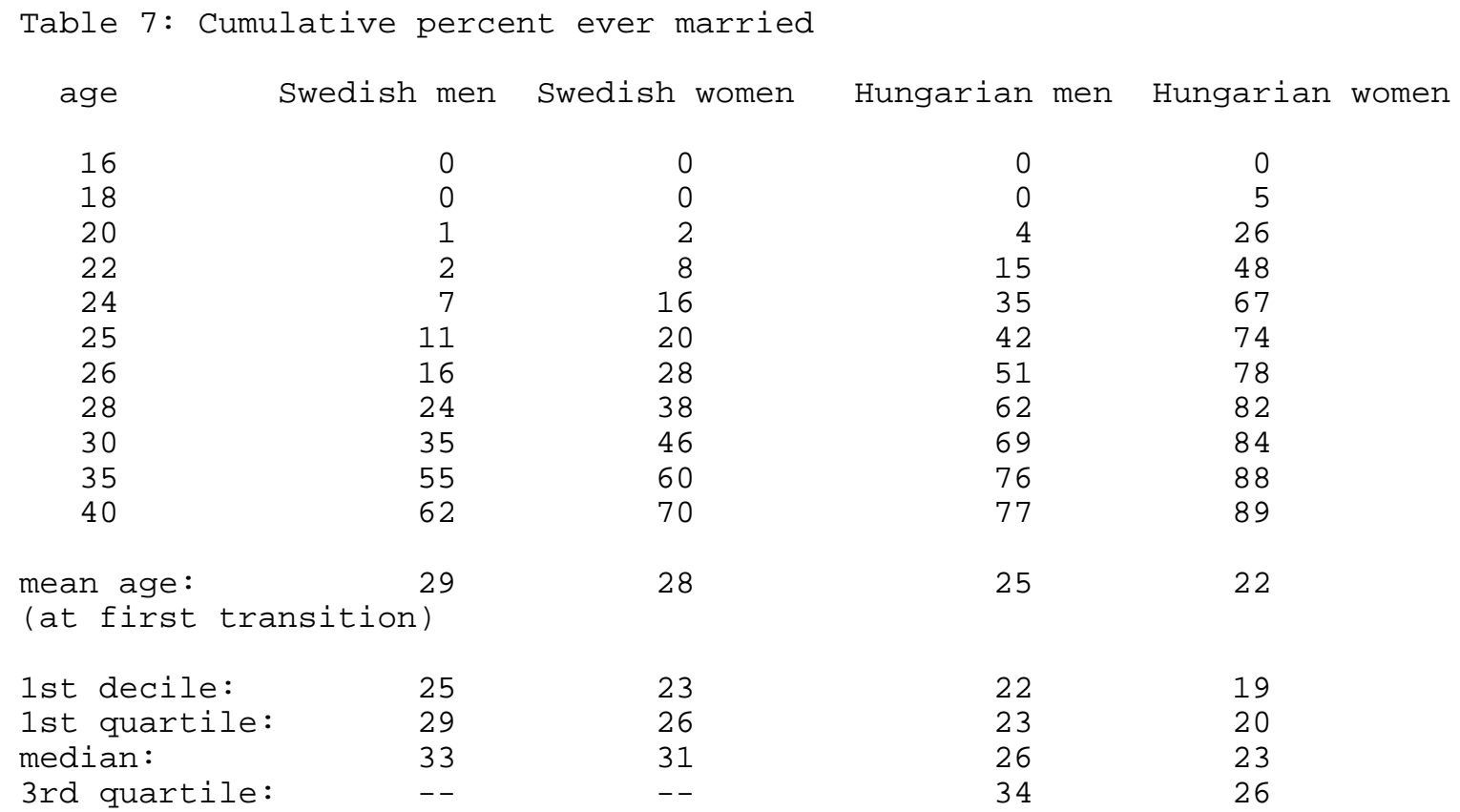


It is evident that the differences between Hungary and Sweden in fractions of people who eventually have any experience of a marriage formation are less pronounced than the differences in marriage-formation patterns as they appear when one only study entries to a first union. Evidently, a lot of people in Sweden marry at some point in time even though this normally not occurs as an entry to a first union. Still, the fractions of never married people in Sweden are higher at almost every single age of study than they are in Hungary.

Next, Table 8 reports the cumulative percent who ever become a parent, for men and women, separately, where entry into parenthood includes both biological and adopted children. This table mainly reveals differences in timing between the two countries where childbearing in Hungary starts at much earlier ages than in Sweden.

\begin{tabular}{|c|c|c|c|c|}
\hline Swedish & men & Swedish women & Hungarian men & Hungarian women \\
\hline 16 & 0 & 0 & 0 & 0 \\
\hline 18 & 0 & 1 & 0 & 3 \\
\hline 20 & 1 & 6 & 4 & 17 \\
\hline 22 & 6 & 15 & 9 & 38 \\
\hline 24 & 15 & 29 & 25 & 57 \\
\hline 25 & 21 & 36 & 34 & 64 \\
\hline 26 & 26 & 43 & 41 & 71 \\
\hline 28 & 40 & 57 & 55 & 81 \\
\hline 30 & 54 & 68 & 63 & 84 \\
\hline 35 & 74 & 83 & 75 & 91 \\
\hline 40 & 79 & 87 & 79 & 93 \\
\hline $\begin{array}{l}\text { mean age: } \\
\text { (at transition) }\end{array}$ & 28 & 26 & 26 & 24 \\
\hline 1st decile: & 23 & 21 & 23 & 20 \\
\hline 1st quartile: & 26 & 24 & 24 & 21 \\
\hline median: & 30 & 27 & 28 & 24 \\
\hline 3rd quartile: & 36 & 32 & 35 & 27 \\
\hline
\end{tabular}

We proceed and present three measures that combine information on the status of being a parent and the union status during parenthood. We present tables that give information about experiences of the combination of being a parent and being in any union (Table 9), in a marital union (Table 10), or out of union (Table 11), with the attainment of the combination of these states at either a childbirth (or adoption) or a union event, whichever comes last. The entry into the state of ever being both a parent and in a union can thus occur at the childbirth of a partnered person or by the union formation of a lone parent. Similarly, the entry into the state of ever being a parent out of a union can occur by the entry into parenthood by a person who does not live in a union or by the union dissolution of a parent. We do not discriminate between union orders so any combination of interest can be attained at any union order.

Note that these measures give no information on real living arrangements of people, i.e., on whether parents actually live together with their kids in a specific union. In this data representation, we have, for example, not used information on whether children continue to live with a parent after a union disruption or whether new stepchildren arrive to a family. We just use the information on parity changes of the adult respondents. 
Differences between Hungary and Sweden are not that dramatic in these tabulations and they mainly reflect differences in patterns of entry into parenthood, union formation, and marriage formation as they have already appeared in the tables presented so far. Women in Hungary, for example, start childbearing at much earlier ages than do women in Sweden. Table 11 also reflects patterns in union dissolution in the two countries and we can see that around one quarter of women in both Hungary and Sweden will have any experience of being a parent but not in a union before age 40. In these countries, such a situation most often appears as a result of union dissolution. We will return to patterns of union transformations in a later section of our presentation.

\begin{tabular}{|c|c|c|c|c|}
\hline Swedish & men & Swedish women & Hungarian men & Hungarian women \\
\hline 16 & 0 & 0 & 0 & 0 \\
\hline 18 & 0 & 1 & 0 & 3 \\
\hline 20 & 1 & 5 & 3 & 16 \\
\hline 22 & 6 & 14 & 9 & 36 \\
\hline 24 & 15 & 28 & 25 & 54 \\
\hline 25 & 20 & 35 & 34 & 62 \\
\hline 26 & 26 & 41 & 41 & 70 \\
\hline 28 & 39 & 55 & 55 & 80 \\
\hline 30 & 53 & 66 & 63 & 83 \\
\hline 35 & 72 & 81 & 75 & 90 \\
\hline 40 & 77 & 85 & 79 & 92 \\
\hline $\begin{array}{l}\text { mean age: } \\
\text { (at transition) }\end{array}$ & 28 & 26 & 26 & 24 \\
\hline 1st decile: & 23 & 22 & 23 & 20 \\
\hline 1st quartile: & 26 & 24 & 24 & 21 \\
\hline median: & 30 & 28 & 28 & 24 \\
\hline 3rd quartile: & 37 & 33 & 35 & 27 \\
\hline
\end{tabular}

\begin{tabular}{|c|c|c|c|c|}
\hline Swedish & men & Swedish women & Hungarian men & Hungarian women \\
\hline 16 & 0 & 0 & 0 & 0 \\
\hline 18 & 0 & 0 & 0 & 2 \\
\hline 20 & 0 & 1 & 3 & 14 \\
\hline 22 & 1 & 5 & 7 & 34 \\
\hline 24 & 5 & 11 & 23 & 52 \\
\hline 25 & 7 & 15 & 32 & 60 \\
\hline 26 & 11 & 21 & 38 & 68 \\
\hline 28 & 17 & 31 & 51 & 77 \\
\hline 30 & 29 & 40 & 61 & 81 \\
\hline 35 & 51 & 56 & 72 & 87 \\
\hline 40 & 60 & 67 & 76 & 90 \\
\hline $\begin{array}{l}\text { mean age: } \\
\text { (at transition) }\end{array}$ & 30 & 29 & 27 & 24 \\
\hline 1st decile: & 26 & 24 & 23 & 20 \\
\hline 1st quartile: & 30 & 27 & 25 & 22 \\
\hline median: & 35 & 32 & 28 & 24 \\
\hline 3 rd quartile: & -- & -- & 39 & 28 \\
\hline
\end{tabular}




\begin{tabular}{|c|c|c|c|c|}
\hline Swedish & men & Swedish women & Hungarian men & Hungarian women \\
\hline 16 & 0 & 0 & 0 & 0 \\
\hline 18 & 0 & 0 & 0 & 1 \\
\hline 20 & 0 & 2 & 0 & 3 \\
\hline 22 & 1 & 4 & 1 & 5 \\
\hline 24 & 2 & 7 & 3 & 8 \\
\hline 25 & 3 & 8 & 3 & 9 \\
\hline 26 & 4 & 10 & 4 & 10 \\
\hline 28 & 8 & 12 & 4 & 13 \\
\hline 30 & 10 & 15 & 7 & 16 \\
\hline 35 & 16 & 21 & 10 & 22 \\
\hline 40 & 22 & 27 & 14 & 26 \\
\hline $\begin{array}{l}\text { mean age: } \\
\text { (at transition) }\end{array}$ & 31 & 29 & 30 & 28 \\
\hline 1st decile: & 30 & 26 & 35 & 26 \\
\hline 1st quartile: & -- & 38 & -- & 39 \\
\hline median: & -- & -- & -- & -- \\
\hline 3rd quartile: & -- & -- & -- & -- \\
\hline
\end{tabular}

Finally, we present a number of measures that give information on the combination of statuses and order of events. As life-table representations these measures are a bit more problematic than the tables presented so far since the populations that are under "risk" of experiencing such combinations of statuses and events consist of very different mixes of people. In these estimations we do, for example, not censor for the attainment of any specific single event so our "risk population" might consist also of persons who are not really under active risk of experiencing the certain combination of events and statuses that we look for. We are aware of this statistical problem but still think these tabulations give valuable information about the context in which families are formed. These tables should then be seen as purely descriptive devices for experiences of the populations considered. As such, they give telling information on differences in actual experiences of family formation in Sweden and Hungary. However, since the exposure groups of our estimations contain very different types of persons, it is difficult to know the reason why one gets a specific pattern and why patterns look different in different study populations.

The first table of this kind (Table 12) presents the cumulative percentages by age who ever get married while also living in a first union. In Sweden, just around half of both men and women ever experience such an event before age 40 despite the fact that around two thirds of them eventually get married (Table 7). Evidently, first marriage in Sweden often occurs in higherorder unions.

The following four tables (Tables 13-16) all give information about the context where people give birth to their first child (or are adopting their first child), with cumulative percentages of men and women who will ever experience the entry into parenthood while at the same thing living in a first union (Table 13), in any union at all (Table 14), in a marriage (Table 15), or not in a union (Table 16). 
Table 12: Cumulative percent ever "married ever during a first union" (including those who marry directly)

age Swedish men Swedish women Hungarian men Hungarian women

$\begin{array}{lrrrr}16 & 0 & 0 & 0 & 0 \\ 18 & 0 & 0 & 0 & 5 \\ 20 & 1 & 2 & 4 & 26 \\ 22 & 2 & 7 & 15 & 48 \\ 24 & 7 & 14 & 34 & 66 \\ 25 & 10 & 18 & 42 & 72 \\ 26 & 15 & 24 & 48 & 76 \\ 28 & 21 & 31 & 59 & 81 \\ 30 & 29 & 36 & 64 & 84 \\ 35 & 43 & 45 & 69 & 86 \\ 40 & 48 & 53 & 71 & 22 \\ & & & & \\ \text { an } \text { age: } & 29 & 28 & & 19 \\ \text { transition }) & & & 25 & 20 \\ & & 23 & 23 & 23 \\ \text { decile: } & 25 & 27 & 27 & 26\end{array}$

Table 13: Cumulative percent ever "having a first birth ever in a first union"

age Swedish men Swedish women Hungarian men Hungarian women

$\begin{array}{lrrrr}16 & 0 & 0 & 0 & 0 \\ 18 & 0 & 1 & 0 & 3 \\ 20 & 1 & 5 & 3 & 15 \\ 22 & 5 & 12 & 8 & 34 \\ 24 & 13 & 23 & 23 & 52 \\ 25 & 17 & 28 & 31 & 59 \\ 26 & 21 & 33 & 37 & 65 \\ 28 & 31 & 44 & 50 & 76 \\ 30 & 42 & 52 & 55 & 81 \\ 35 & 55 & 60 & 68 & 82 \\ 40 & 57 & 62 & & 23 \\ & & & 26 & \\ \text { an age: } & 28 & 26 & & 20 \\ t \text { transition } & & & 23 & 22 \\ & & 22 & 25 & 24 \\ t \text { decile: } & 24 & 25 & 28 & \end{array}$


Table 14: Cumulative percent ever "having a first birth ever in any union" age Swedish men Swedish women Hungarian men Hungarian women

$\begin{array}{lrrrr}16 & 0 & 0 & 0 & 0 \\ 18 & 0 & 1 & 0 & 3 \\ 20 & 1 & 5 & 3 & 15 \\ 22 & 5 & 13 & 8 & 35 \\ 24 & 14 & 27 & 23 & 53 \\ 25 & 19 & 33 & 32 & 60 \\ 26 & 25 & 39 & 39 & 67 \\ 28 & 38 & 53 & 52 & 76 \\ 30 & 51 & 63 & 73 & 86 \\ 35 & 69 & 76 & 76 & 87 \\ 40 & 73 & 79 & & 24 \\ & & & 27 & \\ \text { an age: } & 28 & 26 & & 20 \\ t \text { transition } & & & 23 & 21 \\ & & 22 & 25 & 28\end{array}$

Table 15: Cumulative percent ever "having a first birth ever in any marriage"

age Swedish men Swedish women Hungarian men Hungarian women

$\begin{array}{lrrrr}16 & 0 & 0 & 0 & 0 \\ 18 & 0 & 0 & 0 & 2 \\ 20 & 0 & 1 & 2 & 13 \\ 22 & 1 & 2 & 6 & 32 \\ 24 & 3 & 5 & 21 & 49 \\ 25 & 4 & 7 & 29 & 57 \\ 26 & 5 & 9 & 36 & 64 \\ 28 & 9 & 15 & 48 & 72 \\ 30 & 14 & 20 & 68 & 76 \\ 35 & 23 & 26 & 72 & 83 \\ 40 & 26 & 28 & & \\ & & & 27 & \\ \text { an age: } & 30 & & & 24 \\ t \text { transition } & & 27 & 23 & 22 \\ & & 33 & 25 & 25 \\ \text { t decile: } & 29 & -- & 29 & 30\end{array}$




\begin{tabular}{|c|c|c|c|c|}
\hline Swedish & men & Swedish women & Hungarian men & Hungarian women \\
\hline 16 & 0 & 0 & 0 & 0 \\
\hline 18 & 0 & 0 & 0 & 1 \\
\hline 20 & 0 & 1 & 0 & 2 \\
\hline 22 & 1 & 2 & 1 & 3 \\
\hline 24 & 1 & 3 & 2 & 4 \\
\hline 25 & 1 & 3 & 2 & 4 \\
\hline 26 & 2 & 3 & 2 & 4 \\
\hline 28 & 2 & 4 & 2 & 4 \\
\hline 30 & 2 & 4 & 2 & 4 \\
\hline 35 & 3 & 4 & 2 & 5 \\
\hline 40 & 3 & 5 & 2 & 5 \\
\hline $\begin{array}{l}\text { mean age: } \\
\text { (at transition) }\end{array}$ & 26 & 25 & 22 & 22 \\
\hline 1st decile: & -- & -- & -- & -- \\
\hline 1st quartile: & -- & -- & -- & -- \\
\hline median: & -- & -- & -- & -- \\
\hline 3rd quartile: & -- & -- & -- & -- \\
\hline
\end{tabular}

The tables that describe the different contexts of entry to parenthood (Tables 13-16) reveal, among other things, that first childbearing in Sweden not is confined to a first union and certainly not to marriage but nevertheless to a union. For Hungary, on the other hand, Tables 13-15 look very similar to each other simply because there is hardly any distinction between a first union, any union, or any marriage for most people in that country. For both Hungary and Sweden, there are very small fractions of men and women who report that they become a parent while not living together with a partner.

In our next section of tabulations, we will proceed with a presentation of the fates that men and women face after they have entered a union. 


\section{B. MEASURES OF UNION TRANSFORMATION AND UNION DISRUPTION FOR UNIONS OF MEN AND WOMEN}

In this section, we describe various experiences of men and women after they have entered a union. We use information on unions as reported by both men and women but pool them together. We thus present life-table estimates for persons in unions and report the cumulative percent who experience a certain event at every exact single year of union duration for the first five years of a union and then at exact durations 7, 10, and 15 years from the union formation. In the life tables where we exclusively focus on dissolution of unions we also give that percentage at 20 years after the union formation. In all our life-table estimations, we censor our observation at the possible but rare event of a reported death of a partner.

Concern is sometimes expressed about the reliability of men's reporting about issues such as union formation and even about the possibility of non-reporting of unions that does not lead to marriage or to childbearing. In the case of Hungary and Sweden, we have experimented with the estimation of separate life tables for unions of the two sexes but we found no really striking differences in patterns of union transformations as reported by men and women. Thus there should be no problem in combing unions reported by men with those reported by women.

Our first two life tables take the formation of a union of a childless person as the starting point. In Table 17, we present a single-decrement life table where we describe the pattern of how such unions transform into unions where people have children, if we ignore the competing event of union dissolution and thus censor our observations at such an event. Toulemon and Lapierre-Adamcyk (2000) have previously presented a number of tabulations of that kind for France. For Hungary and Sweden, we can notice that practically all remaining unions eventually end up in childbearing. However the pace of entry into parenthood is much faster in Hungary than in Sweden: more than half of Hungarian childless persons had a child already after two years of union duration and $72 \%$ of them had a child after three years from the formation of their union. In Sweden, it takes seven years before three out of four unions started by a childless person have resulted in childbearing.

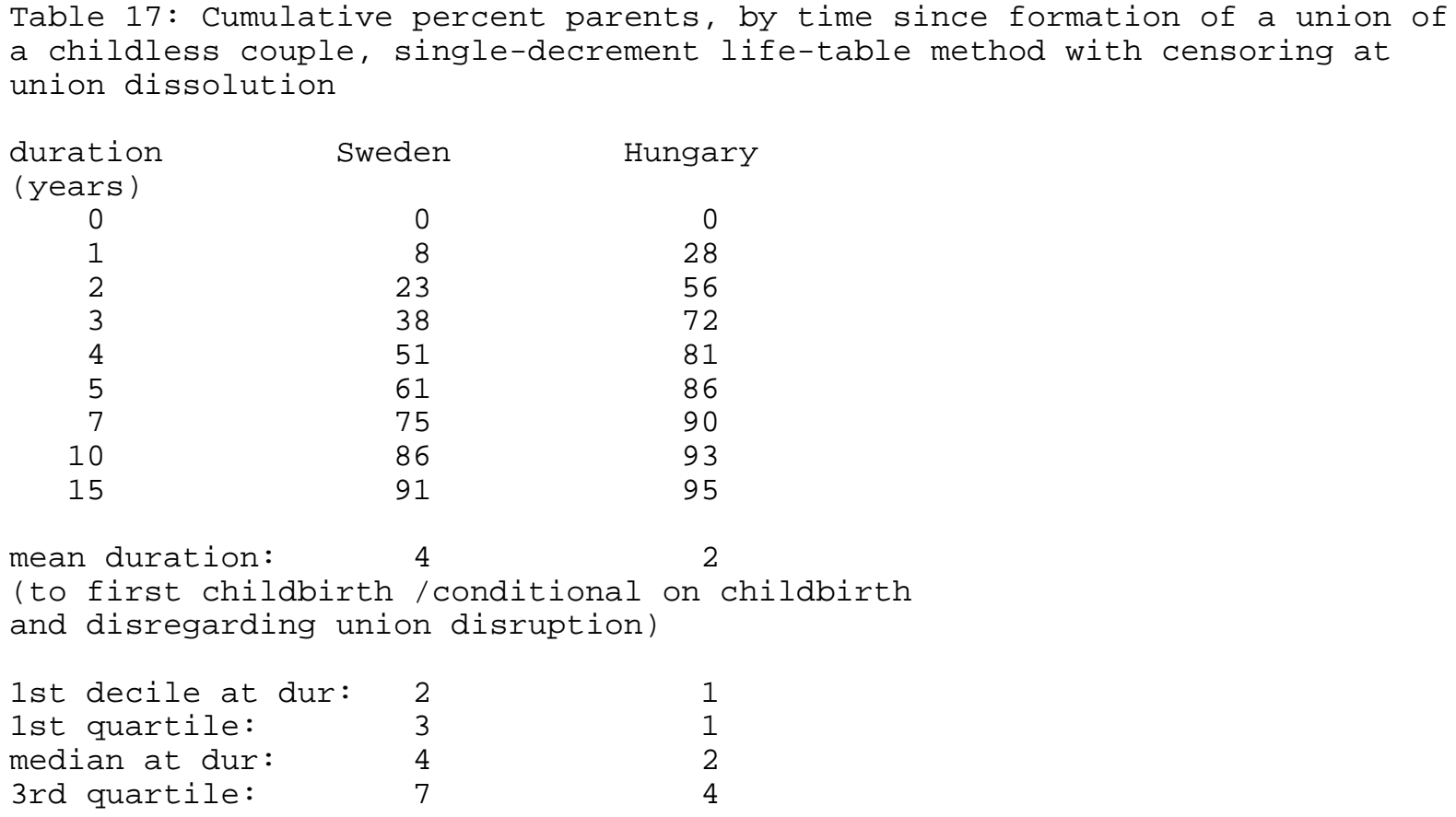


In Table 18, we similarly describe the patterns of how unions of a childless person are being dissolved if we instead ignore the competing event of childbearing and censor at that event. We thus present a single-decrement life table of the cumulative percent separated of unions of a childless person. Evidently, childless unions are relatively unstable and large fractions of them are getting dissolved so that just half of them remain after 7 years in Sweden and 12 years in Hungary.

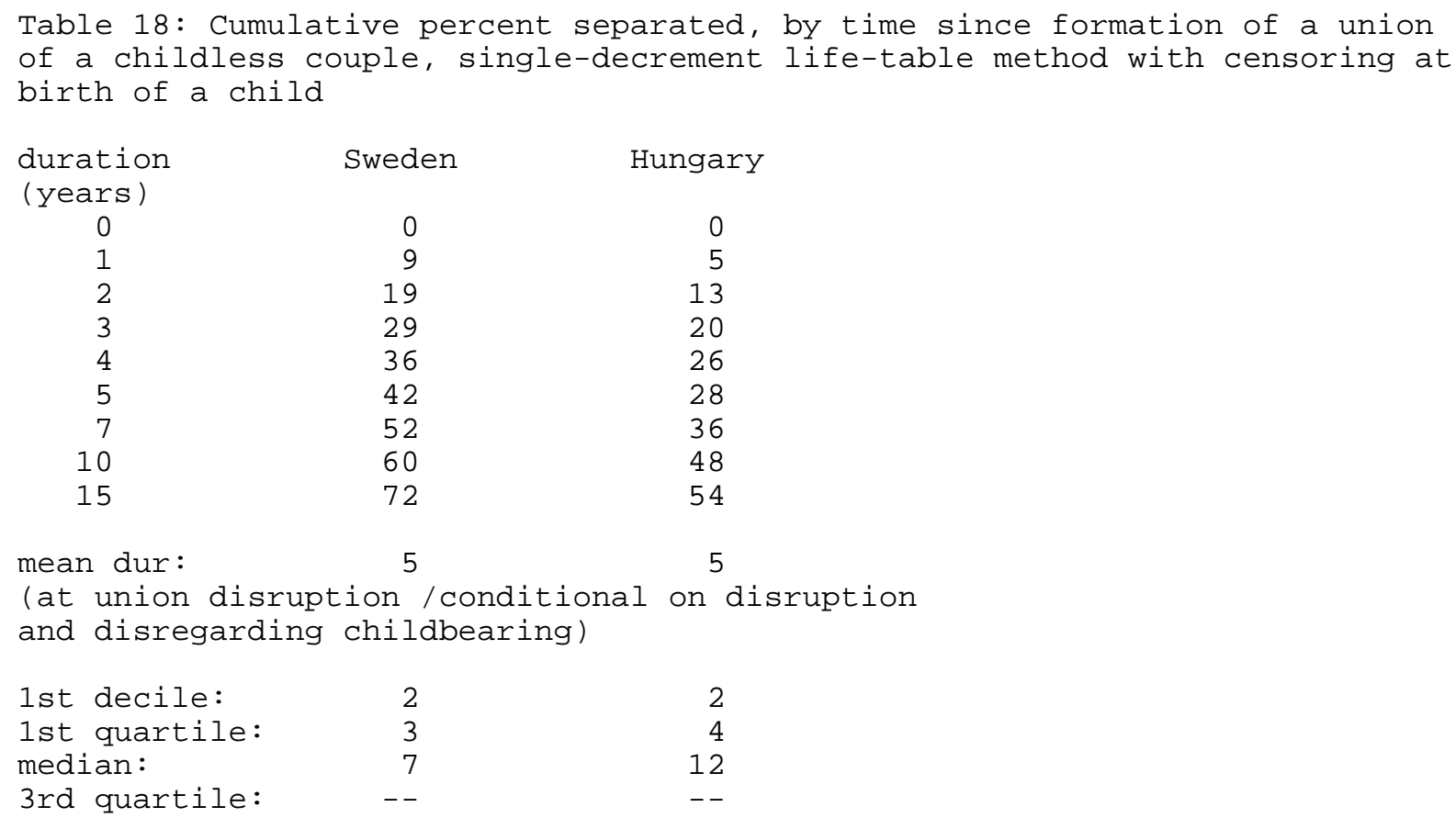

We proceed with a similar description of the destiny of consensual unions: how they either transform into a formal marriage or get dissolved. Our first table (Table 19) is a singledecrement life-table of the cumulative percent married, by time since formation of the consensual union. Individuals under risk are here censored at the alternative event of union disruption so this table gives information on the pure propensity of partners in consensual unions to transform their unions into a marriage. The table reveals that high fractions of remaining unions eventually end up in a marriage, both in Hungary and in Sweden. However, the transformation of consensual unions into marriage occurs at a much faster rate in Hungary than in Sweden and is there concentrated to the first few years of the union. Again, we need to keep in mind that the patterns of marriage formation for Sweden still is affected upwards by the extraordinary marriage boom of 1989.

In Table 20, we instead present the cumulative percent of consensual unions that are being dissolved if we ignore the alternative event of a transformation of the union into a marriage and censor at that event. The table shows that consensual unions are very unstable in both countries. Union disruption is common and the majority of remaining consensual unions are dissolved already at a duration of 5-7 years from union formation. Consensual unions in Hungary are less stable than those in Sweden.

In our presentations of life tables related to consensual unions in Hungary, we find that we cannot give a complete picture of their dynamics. Since such unions are relatively rare in Hungary and also more short-lived there than in Sweden, we can only follow them during their early phases. The size of our data does not allow for more: the number of exposures soon 
becomes very small and we have to stop our observation. Consequently, we can neither calculate comparable mean values of union durations (conditional on exit or truncated after 15 years) in the manner that we can for Sweden.

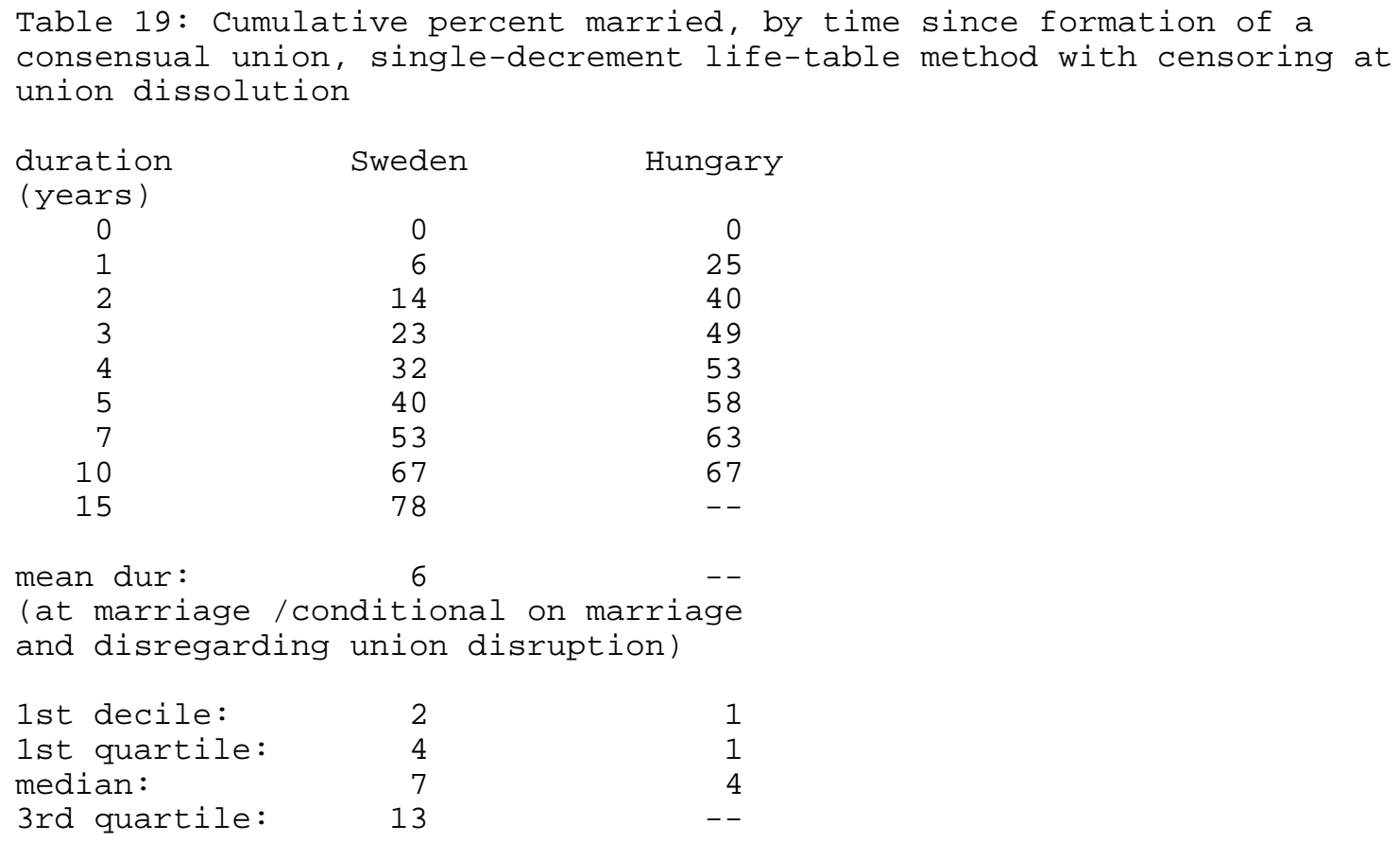

$\begin{array}{ccc}\begin{array}{c}\text { duration } \\ \text { (years) }\end{array} & \text { Sweden } & \text { Hungary } \\ 0 & 0 & 0 \\ 1 & 6 & 25 \\ 2 & 14 & 40 \\ 3 & 23 & 49 \\ 4 & 32 & 53 \\ 5 & 40 & 58 \\ 7 & 53 & 63 \\ 10 & 67 & 67 \\ 15 & 78 & --\end{array}$


We complete our presentation of patterns of transformations of consensual unions with two life tables that are estimated by the competing-risks life-table method. This gives a description of the actual fractions of partners in consensual unions who actually end up either in a marriage (Table 21) or in disruption (Table 22) at various durations since the union formation. In addition, we can present the sum of the two tables, which then gives information about the fractions of consensual unions that stop to be a union of that kind (Table 23).

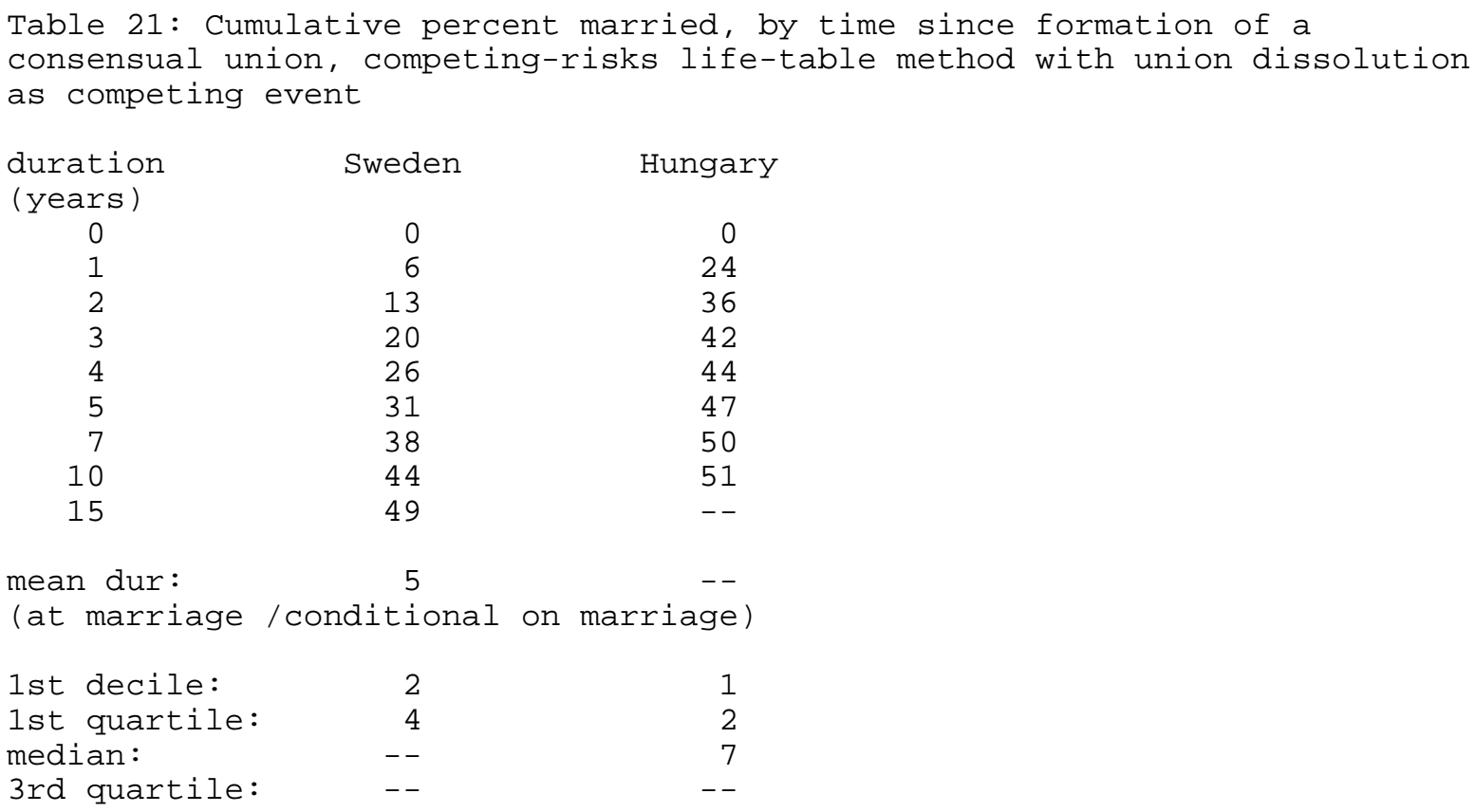

Table 22: Cumulative percent separated, by time since formation of a consensual union, competing-risks life-table method with marriage formation as competing event

$\begin{array}{ccc}\begin{array}{c}\text { duration } \\ \text { (years) }\end{array} & \text { Sweden } & \text { Hungary } \\ 0 & 0 & 0 \\ 1 & 8 & 10 \\ 2 & 17 & 20 \\ 3 & 25 & 25 \\ 4 & 31 & 30 \\ 5 & 34 & 32 \\ 7 & 39 & 34 \\ 10 & 41 & 38 \\ 15 & 43 & -- \\ & & \\ \text { mean dur: } & 3 & -- \\ \text { (at union disruption } & \\ & & \text { disruption) } \\ \text { 1st decile: } & 2 & 3 \\ \text { 1st quartile: } & 3 & -- \\ \text { median: } & -- & -- \\ \text { 3rd quartile: } & -- & \end{array}$




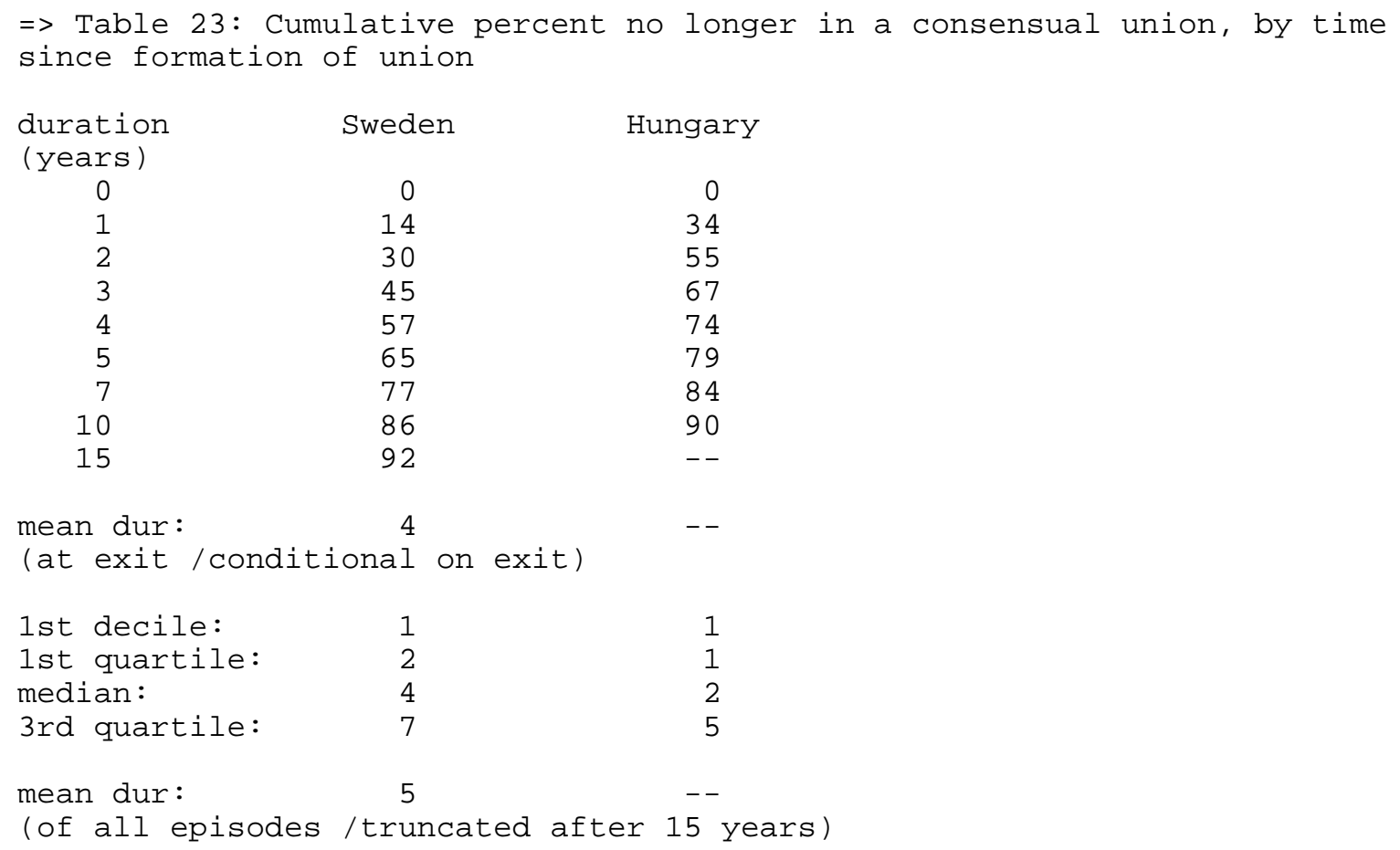

Again, these tables demonstrate that a consensual union merely is a transitional phase in peoples lives, even in a country like Sweden. In both countries, around 40 percent of such unions end up in disruption and most of the remaining unions are transformed into marriages, with a much faster rate of the latter type of union transformation in Hungary than in Sweden.

We now proceed with a number of life tables that provide more information on patterns in union dissolution in Sweden and Hungary. We present life tables on disruptions of (i) unions begun as a consensual union (without censoring at any transformation of that union into a formal marriage) and (ii) unions begun as a direct marriage, as well as for (iii) all unions taken together. Again we use unions of all orders as the basis for our computations and the possible event of union disruption is modeled at the date when respondents reported that they stopped living with their partner. In this part of our description, we follow each union up to a maximal duration of 20 years ${ }^{1}$.

Table 24 displays very similar patterns of union dissolution for unions started as a consensual union in Hungary and Sweden. In the same way, both countries have very similar patterns of union dissolution for unions begun as a marriage (Table 25). The rate of union dissolution is much higher for the former type of union: more than half of these unions eventually end up in a disruption while only a quarter of unions begun as a marriage end up in a separation.

Since patterns in union formation are very different in Hungary and Sweden (see Section 1A), we will nevertheless find very different levels of overall rates of union dissolution between the two countries (Table 25). When practically all unions in Sweden start as a cohabitation, the overall pattern of union dissolution will be very similar to that in Table 24. In contrast, more unions in Hungary are instead started as a direct marriage so the overall union-dissolution rate for Hungary is much lower than that for Sweden. More than half of all unions formed in Sweden end up in dissolution while about one third of Hungarian unions end up the same way.

\footnotetext{
${ }^{1}$ In this case, we have enough observations to follow people in unions up the $20^{\text {th }}$ birthday of the union, simply because we do not censor partners in consensual unions if they transform the union into a marriage.
} 
Table 24: Cumulative percent separated, by time since union formation, for unions begun as a cohabitation (without censoring at marriage formation)

$\begin{array}{ccc}\begin{array}{c}\text { duration } \\ \text { (years) }\end{array} & \text { Sweden } & \text { Hungary } \\ 0 & 0 & 0 \\ 1 & 8 & 10 \\ 2 & 18 & 20 \\ 3 & 26 & 26 \\ 4 & 32 & 32 \\ 5 & 37 & 35 \\ 7 & 43 & 40 \\ 10 & 49 & 46 \\ 15 & 55 & 53 \\ 20 & 59 & 58 \\ & & \\ \text { mean dur: } & 5 & 6 \\ \text { (at union disruption } & & 1 \\ & 2 & 3 \\ \text { 1st decile: } & 3 & 14 \\ \text { lst quartile: } & 11 & -- \\ \text { median: } & -- & 12 \\ \text { 3rd quartile: } & & \text { years) }\end{array}$

Table 25: Cumulative percent separated, by time since union formation, for unions begun as a marriage

$\begin{array}{ccc}\begin{array}{c}\text { duration } \\ \text { (years) }\end{array} & \text { Sweden } & \text { Hungary } \\ 0 & 0 & 0 \\ 1 & 3 & 2 \\ 2 & 5 & 4 \\ 3 & 5 & 6 \\ 4 & 5 & 7 \\ 5 & 5 & 9 \\ 7 & 8 & 12 \\ 10 & 14 & 16 \\ 15 & 20 & 20 \\ 20 & 24 & 24 \\ \text { mean dur: } & 9 & 8 \\ \text { (at union disruption /conditional } & \text { on disruption) } \\ \text { 1st decile: } & 8 & 6 \\ \text { 1st quartile: } & -- & -- \\ \text { median: } & -- & -- \\ \text { 3rd quartile: } & -- & -- \\ & & 17 \\ \text { mean dur: } & 17 & \text { years) }\end{array}$


=> Table 26: Cumulative percent separated, by time since union formation, all unions

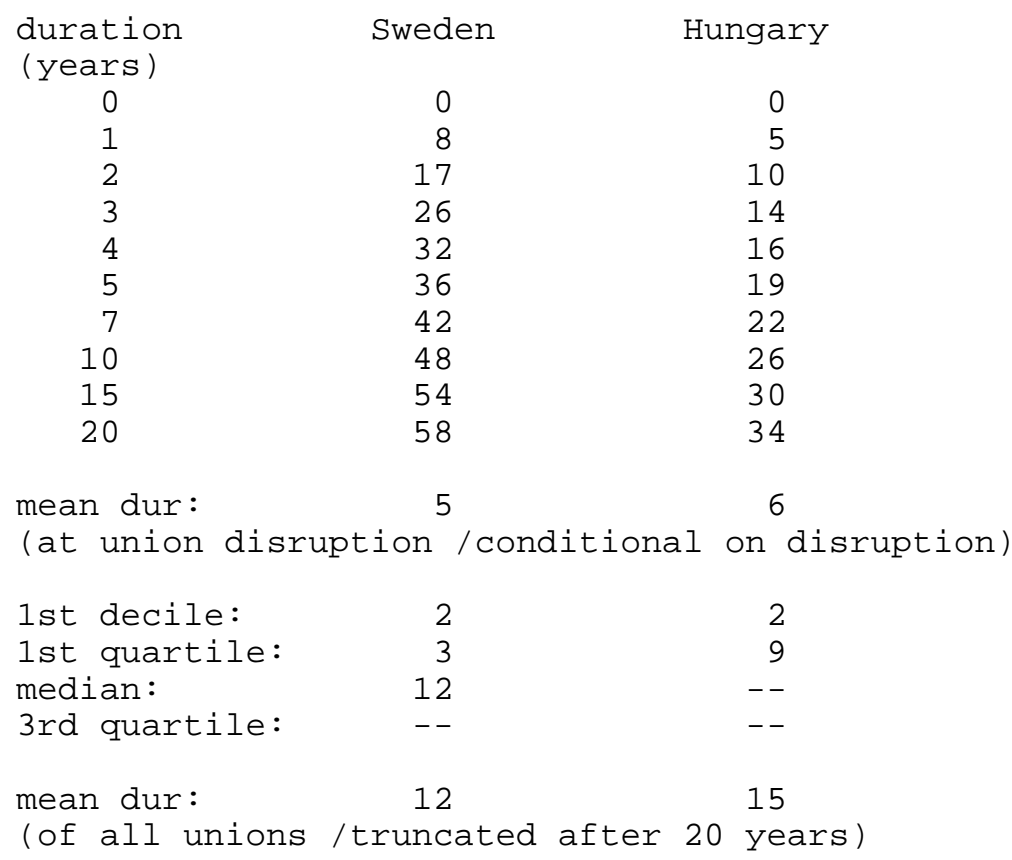

We conclude our presentation of estimates of union-dissolution patterns with two further life tables. The first one (Table 27) gives estimates of union dissolution of marriages by time since marriage formation. This includes all marriages, whether they are preceded by cohabitation or not. About one third of all marriages in Sweden end up in divorce/dissolution while around a quarter of Hungarian marriages are dissolved after a period of 20 years from the marriage date. The propensity to divorce is a bit higher in Sweden than in Hungary at the higher marital durations.

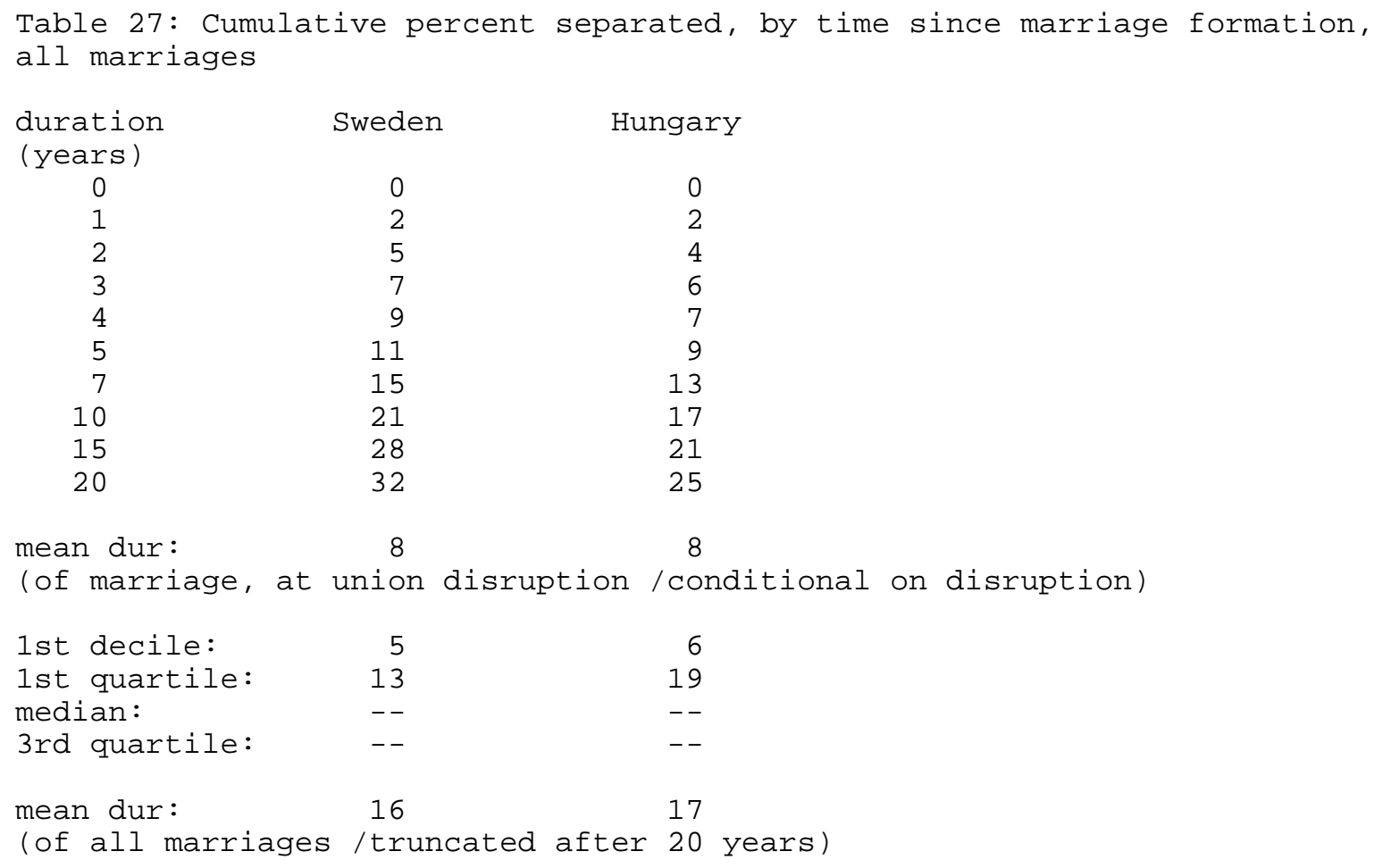


Finally, in Table 28, we report the cumulative percent who experience the dissolution of their union after union formation and entry into parenthood for any union of a parent. This measure gives information on the disruption behavior from yet another important date of the unionformation process but as a measure it is a bit complicated to interpret when our purpose is that of a cross-country comparison. In this case, the population under risk may either enter the risk population by a childbirth or by a union formation, whichever comes last, and is then followed until union disruption or censoring. Nevertheless, our tabulation demonstrates that unions of parents are dissolved at a much higher rate in Sweden than in Hungary ${ }^{2}$. We proceed with the presentation of more family-formation and family-dissolution measures in our next section, where we will study the experiences of various family-transformation events from the point of view of children.

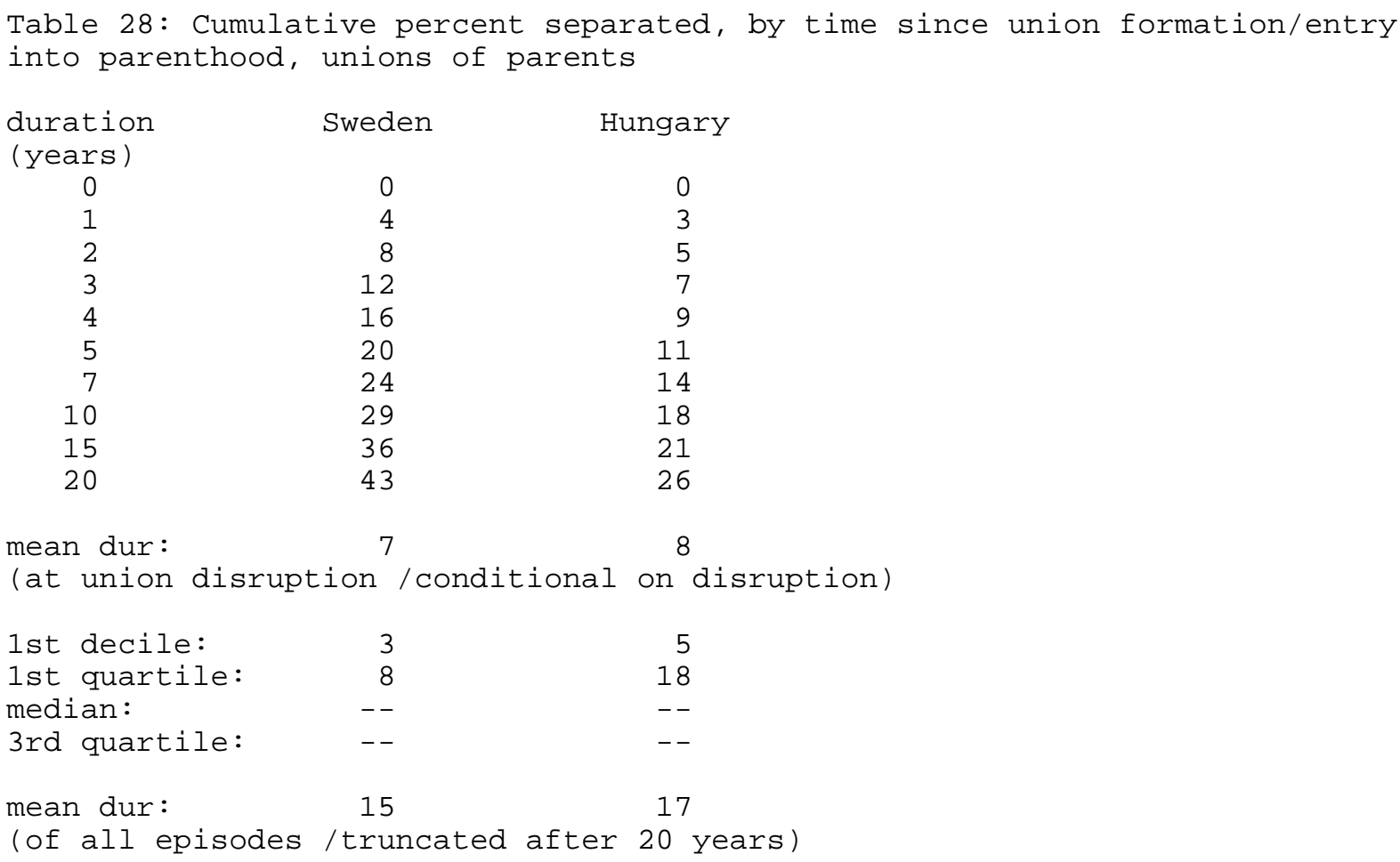

All tables concerning experiences of men and women in unions, as presented so far, give information on experiences in any union regardless of union order. In addition, we have calculated the same set of tables for Hungary and Sweden where we restricted ourselves to first-order unions but we do not show these results here. For Sweden the patterns do not change much when we exclude higher-order unions from our calculations. For Hungary, on the other hand, some deviations do occur since many consensual unions there are formed after a first union. Such unions are less stable than first-order ones, which more often end up in marriage. However, an exclusion of higher-order unions in Hungary results in even smaller number of exposed individuals and thus gives even less information on the consensual-union behaviour in that country.

\footnotetext{
${ }^{2}$ In principle, we can as well construct a similar measure of the cumulative percent separated for married respondents with kids. However, we refrain from such a presentation since, in this case, the time variable (the duration of the status as a parent in marriage) for Sweden mostly will depict the time since marriage formation (of parents) while for Hungary it will describe mainly time since entry into parenthood (of married persons). The diversity in union-formation behavior between countries makes a cross-country comparison with such a measure rather dubious.
} 
Before turning to our presentation of children's experiences of various family transformations, we will complete our presentation of the adult individuals' experiences of different family types with a few diagrams which present fractions of time spent in different family types at different ages. These diagrams are calculated from the time that survey respondents reported they had spent in different family statuses during the calendar-year period which we have used as the basis for our synthetical-cohort tables.

We present two diagrams for Sweden and two for Hungary with one diagram for each sex and country. The diagrams display the distribution of men and women over family types at each exact age from age 15 to age 40. Finally, the information in these diagrams is summarized in Table 29, which shows the total fraction of time that adult individuals would spend in different family types during their reproductive ages if the patterns look like those presented in our diagrams.

Both the diagrams and Table 29 reveal very contrasting patterns in the family experiences of Swedes and Hungarians. Swedish people have a much more extended period of family formation where they spend considerable amounts of time in different family states. They leave the parental home much earlier than do people in Hungary and then typically live on their own for a while, then in a consensual union without children for another period of time, and only later in a union with children and/or in a marriage. By contrast, people in Hungary stay longer time in their parental home and then almost immediately enter into a marital union that very soon also results in childbearing. In the summation of time for the two countries, we will thus find a much larger variation over states for the Swedish adults than for their Hungarian counterparts. Swedish adults also spend less time as parents during the actual age segment, simply because they start their childbearing at higher ages. The same holds for men as compared to women. 


\section{C. SUMMARY MEASURES OF TIME SPENT IN VARIOUS FAMILY STATUSES}

Distribution of Swedish men, by family type, ages $15-40$ years

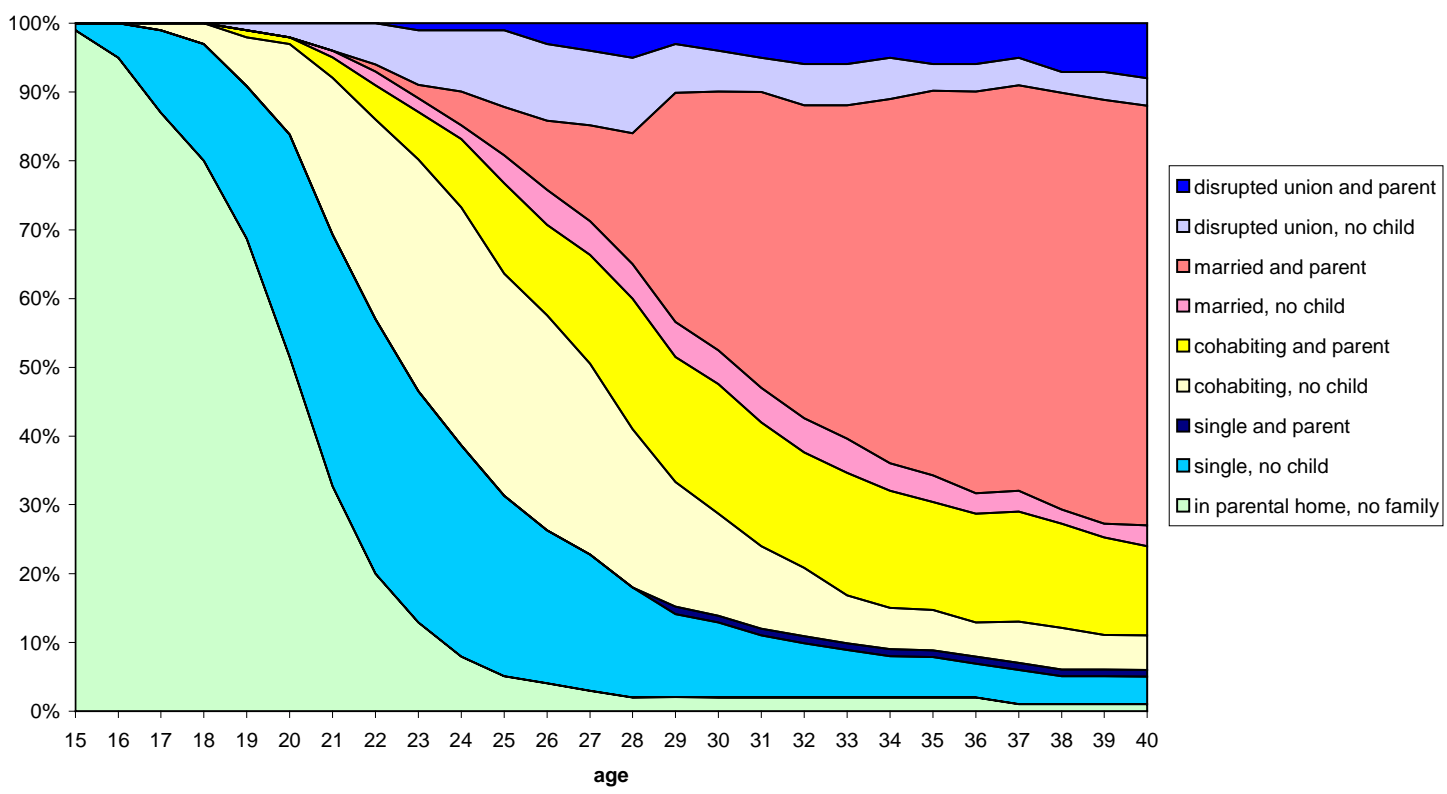

Distribution of Swedish women, by family type, ages $15-40$ years

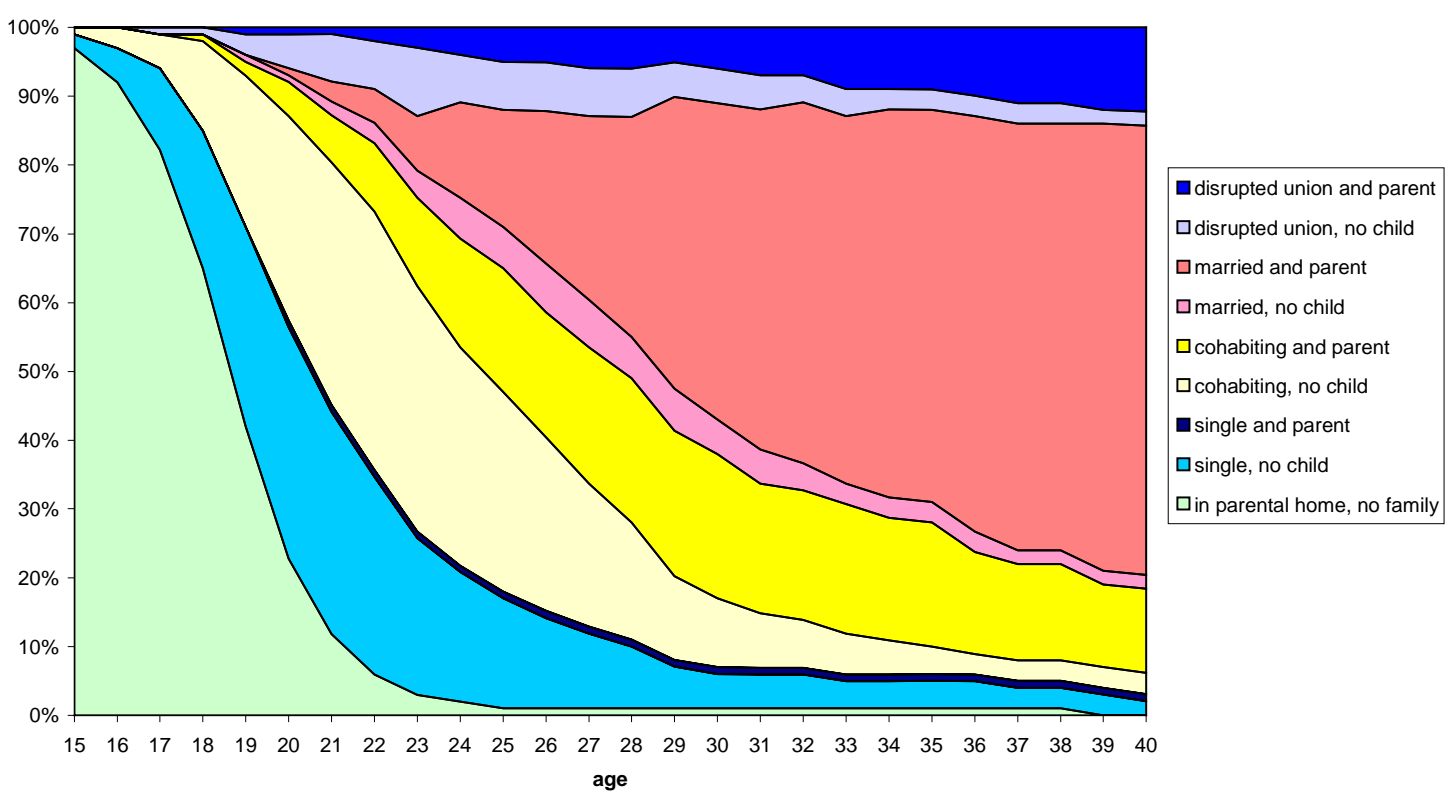


Distribution of Hungarian men, by family type, ages $15-40$ years

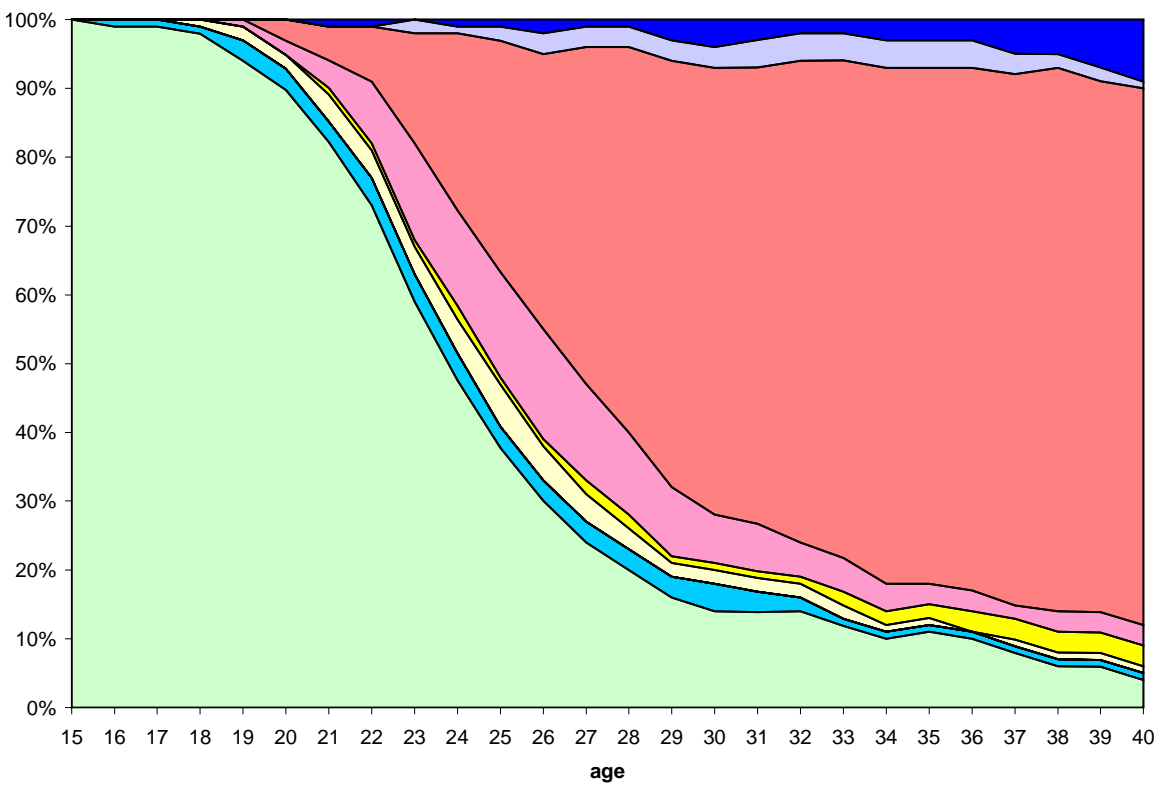

disrupted union and parent

$\square$ disrupted union, no child

$\square$ married and parent

$\square$ married, no child

$\square$ cohabiting and parent

$\square$ cohabiting, no child

- single and parent

$\square$ single, no child

$\square$ in parental home, no family

Distribution of Hungarian women, by family type, ages 15-40 years

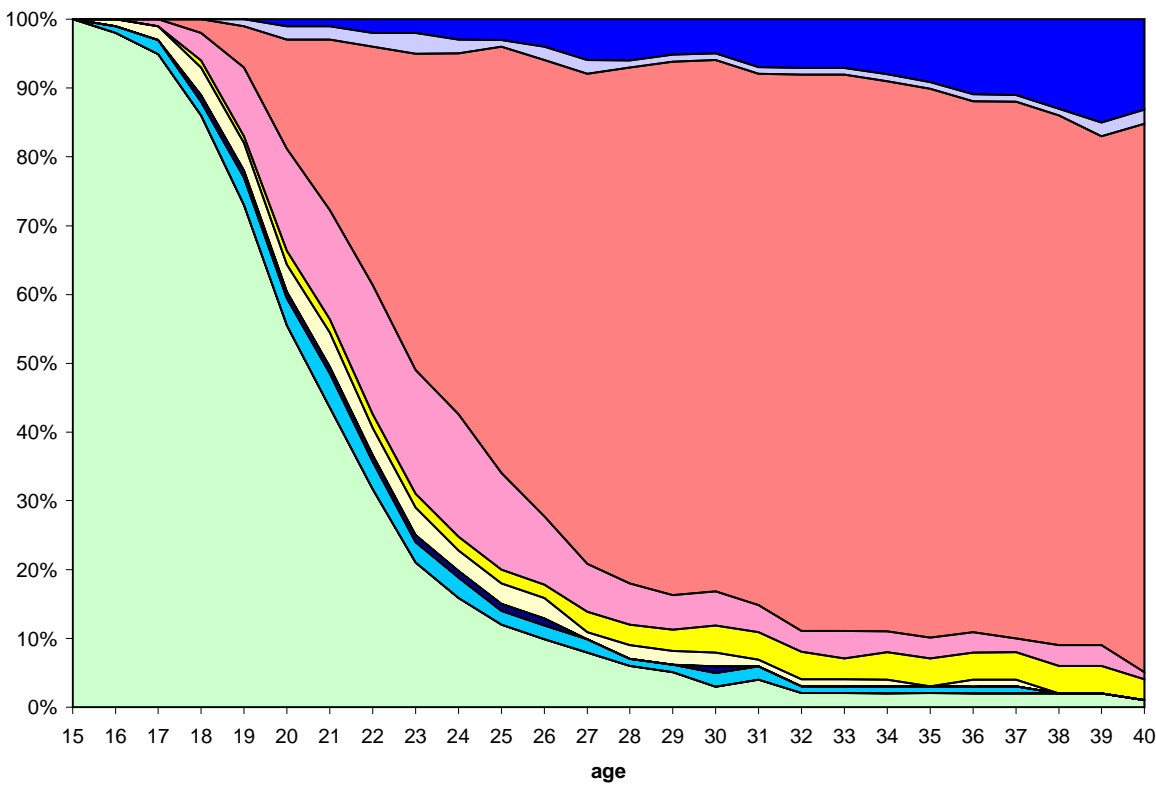

- disrupted union and parent $\square$ disrupted union, no child

$\square$ married and parent

口married, no child

$\square$ cohabiting and parent

$\square$ cohabiting, no child

- single and parent

$\square$ single, no child

Din parental home, no family 
Table 29: Percent of time spent in different family types at ages 15-39 years

Swedish: men women Hungarian: men women

$\begin{array}{lrrrr}\text { in parental home /no family } & 23 & 17 & 41 & 26 \\ \text { single and never in union /no child } & 15 & 12 & 2 & 2 \\ \text { single and never in union /parent } & 0 & 1 & 0 & 1 \\ \text { in consensual union /no child } & 14 & 14 & 2 & 2 \\ \text { in consensual union /parent } & 11 & 13 & 1 & 3 \\ \text { in marriage /no child } & 3 & 3 & 6 & 7 \\ \text { in marriage /parent } & 26 & 31 & 43 & 54 \\ \text { single after family disruption /no child } & 5 & 4 & 2 & 1 \\ \text { single after family disruption /parent } & 3 & 6 & 2 & 5 \\ \text { time in union } & 54 & 61 & 44 & 56 \\ \text {-in union as a parent } & 37 & 44 & 8 & 9 \\ \text {-in union but no child } & 17 & 18 & 46 & 62 \\ \text { time as parent } & & & 44 & 56 \\ \text {-as parent in union } & 41 & 50 & 2 & 6\end{array}$

${ }^{3}$ Single here means "not living in a union". 


\section{CHILDREN'S EXPERIENCES OF FAMILY DYNAMICS, BY AGE (AS REPORTED BY THEIR MOTHERS)}

In this second section, we present various estimates of children's experiences in different types of families: experiences of family dissolution and of family (re-)formation. We use children from the mothers' birth records as our units of observation. We leave out children from the fathers' records since children live separated from their fathers more often than from their mothers (e.g., in case of union disruption) and we then lack information on large segments of these latter children's lives. Again we present estimates for a synthetic cohort corresponding to the period immediately prior to each survey date. In this section, our period of study is the six-year period just before the survey, both for Hungary and for Sweden, relating to children's experiences in 1986/87-1992/93.

In our tables, we describe the family-transformation experiences of biological children in Hungary and Sweden (of parents born in any country of the world). For Hungary, we have no information about the migration histories of mothers so we do not know to what extent reported children really have lived in the country that we intend to study. For Sweden, we have access to such information and we have included all children that are born in the country in our study population. We censor our observations at the $15^{\text {th }}$ birthday of a child. Likewise, we censor a record when a child dies and, in some situations, when a child stops living with its mother. We do not include any information on the family experiences of stepchildren or adopted children in our computations.

In our life tables related to children's experiences of family transformations, we report the cumulative percent of a certain group of children who have experienced a particular event by each of their first four birth days followed by the exact ages $6,9,12$, and 15 years.

In Table 30, we begin with a presentation of the distribution of births that mothers had reported for the six-year period immediately before the survey(s). Their children were born into the following family circumstances:

$\begin{array}{lcc}\text { Table 30: Relative distribution of births } & \text { (percent) } \\ & \text { Sweden } & \text { Hungary } \\ & & 2 \\ \text { children born to mother never in union } & 1 & 2 \\ \text { children born after union disruption } & 3 & 3 \\ \text { => children born to lone mother } & 5 & 90 \\ \text { children born in marriage } & 45 & 6\end{array}$

Very few children in both countries are born to a lone mother. In Hungary, practically all children are born to a married mother while almost half of the children born in Sweden are born to a mother in a consensual union. 


\section{2a. Children's experiences of family disruption}

In our first two life tables related to children's family experiences, we describe their experiences of living outside a traditional family with two (married) biological parents. We present the cumulative percent of children who have ever lived outside a union (Table 31) and outside a marriage (Table 32), by age of child. In these first two tabulations, we count children born to a lone mother - or to an unmarried mother - already at age 0 , i.e., we allow the $\left(1-1_{0}\right)$-values of our life tables to be greater than 0 .

In all our tabulations of children's subsequent experiences of family disruptions, we account for three different ways that a child can leave the union of its family of origin, namely (i) the departure of the father from the family following union dissolution/ divorce, (ii) the death of the father, and (iii) the departure of the child itself from its mother. The latter event can occur either in connection with a union dissolution of the parents, if the child leaves the mother in order to live with the father, or when the child leaves the mother in order to live on its own or with some other person.

Table 31 demonstrates that around one third of all children born in Sweden will experience the situation of not living in a union with the two parents before their $15^{\text {th }}$ birth day while around one quarter of children in Hungary will have the similar experience. If we focus just on marital status, we see that around 60 percent of all children in Sweden will have the experience of not living with two married parents (Table 32).

$\begin{array}{rcc}\text { Table 31: Cumulative percent ever out of union, by age of child } \\ \text { age } & \text { Sweden } & \text { Hungary } \\ 0 & 5 & 3 \\ 1 & 7 & 5 \\ 2 & 9 & 6 \\ 3 & 13 & 8 \\ 4 & 15 & 10 \\ 6 & 20 & 13 \\ 9 & 24 & 17 \\ 12 & 30 & 21 \\ 15 & 34 & 24\end{array}$

$\begin{array}{rcc}\text { Table 32: Cumulative percent ever out of marriage, by age of child } \\ \text { age } & \text { Sweden } & \text { Hungary } \\ & & \\ 0 & 49 & 10 \\ 1 & 50 & 11 \\ 2 & 51 & 11 \\ 3 & 52 & 13 \\ 4 & 53 & 15 \\ 6 & 55 & 18 \\ 9 & 57 & 21 \\ 12 & 60 & 25 \\ 15 & 61 & 28\end{array}$


We proceed with a tabulation of patterns in family dissolution where we only include children who were actually born in a union or a marriage, as the case may be. This is equivalent to the presentation given above but here we start with a $\left(1-1_{0}\right)$-value equal to 0 . We present the cumulative percent of children who experience family dissolution for children born in a union of any kind (Table 33) and for children born in a marriage (Table 35), by age of child. In addition, we present a separate tabulation for children born in a consensual union (Table 34). This gives us an opportunity to compare the family-disruption experiences of children who are born in different types of unions. In the case of children born in a consensual union, we do not censor here for the possible event of a subsequent transformation of the parental union into a marriage. We continue to follow them until either a family dissolution occurs or until their $15^{\text {th }}$ birthday (or until censoring because of their own death).

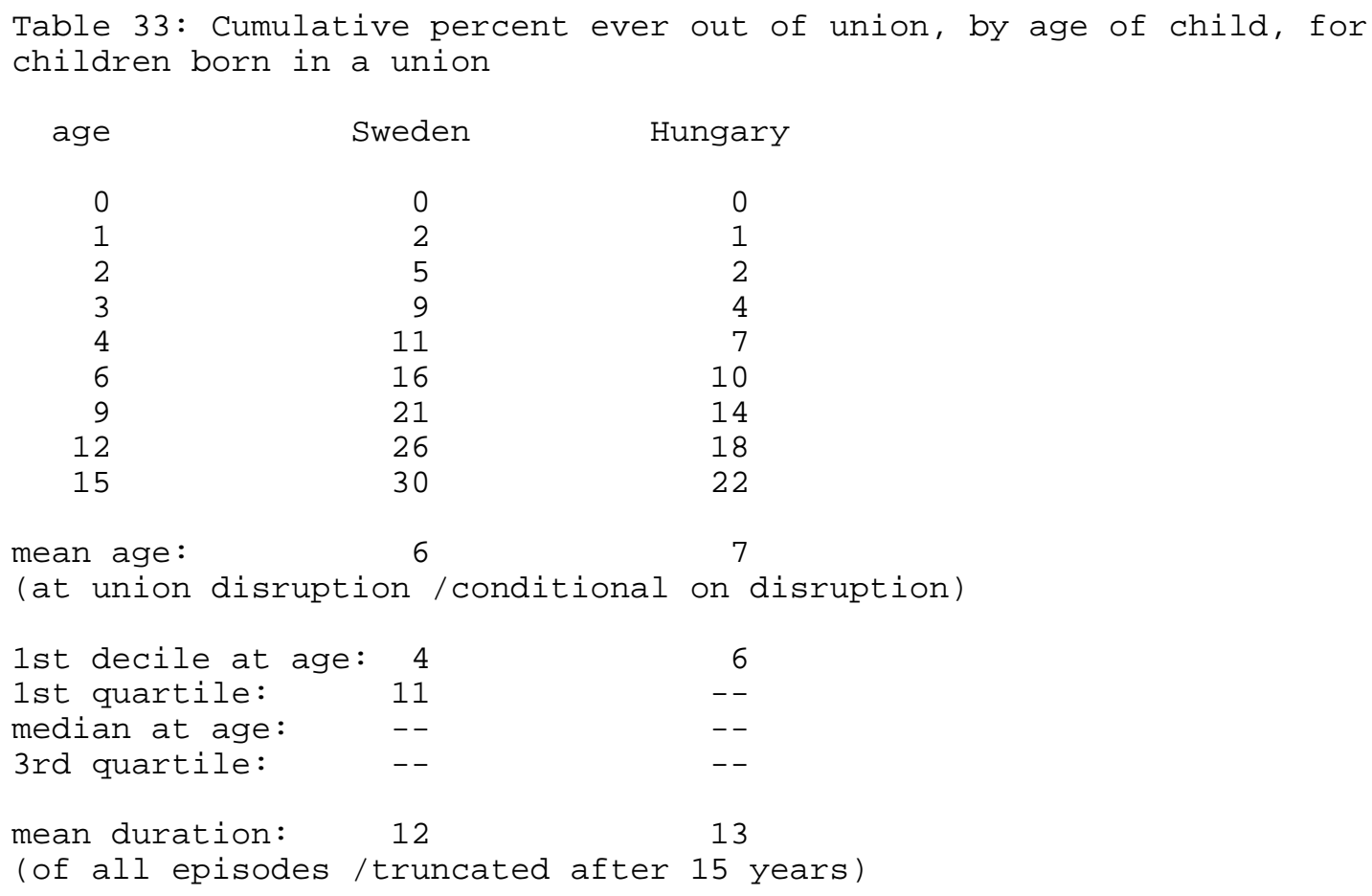

Children born in unions in Sweden have higher levels of experiences of family disruption than children born in Hungarian unions have. The cumulative percent who have ever moved out of the original union are higher in Sweden at every single age. Around 30 percent of all children will experience such an event before their $15^{\text {th }}$ birthday. For Hungary, around 20 percent of children born in a union have by then had that experience.

However, if we focus only on children born in consensual unions, we find that a higher fraction of such children in Hungary will experience a family disruption than corresponding children in Sweden (Table 34). Relatively few children in Hungary are born in that type of union and, evidently, they constitute a relatively selected group that will experience a very unstable family behavior.

Finally, in Table 35, we see that the difference between Hungary and Sweden is not that important when it concerns the family-dissolution experiences of children born in marriages. Around a fifth (Hungary) or a fourth (Sweden) of such children experience a family dissolution of some kind before they turn 15 . 
Table 34: Cumulative percent ever out of union, by age of child, for children born in a consensual union

$\begin{array}{rrr}\text { age } & \text { Sweden } & \text { Hungary } \\ 0 & 0 & 0 \\ 1 & 4 & 7 \\ 2 & 8 & 11 \\ 3 & 13 & 17 \\ 4 & 17 & 26 \\ 6 & 23 & 42 \\ 9 & 27 & 48 \\ 12 & 32 & 52 \\ 15 & 38 & 58\end{array}$

mean age: $6 \quad 5$

(at union disruption /conditional on disruption)

1st decile: 3

1st quartile: $8 \quad 4$

median: $\quad--\quad 11$

3rd quartile: -- --

mean duration: $12 \quad 9$

(of all episodes / truncated after 15 years)

Table 35: Cumulative percent ever out of union/marriage, by age of child, for children born in a marriage

age Sweden Hungary

$\begin{array}{rrr}0 & 0 & 0 \\ 1 & 1 & 1 \\ 2 & 2 & 2 \\ 3 & 5 & 4 \\ 4 & 6 & 5 \\ 6 & 10 & 9 \\ 9 & 15 & 12 \\ 12 & 21 & 17 \\ 15 & 24 & 20\end{array}$

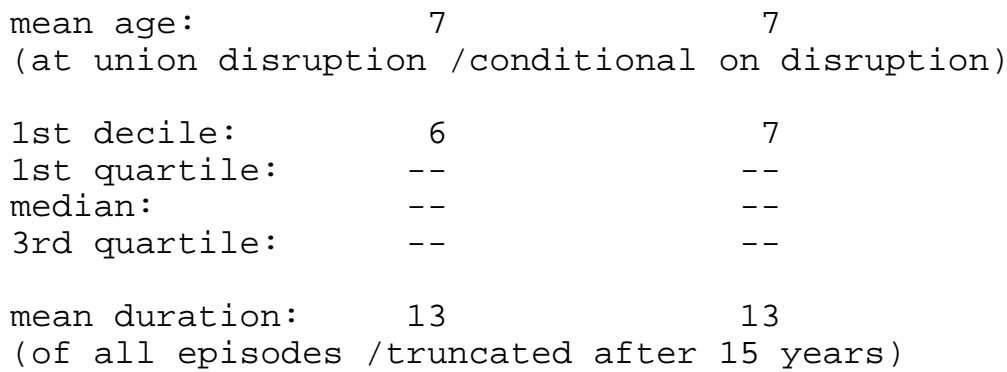




\section{2b. Children's experiences of family formation}

In this sub-section, we begin with a description of the family-formation experiences of children born to a lone mother: we describe to what extent these children subsequently experience a union-formation event by their mother (Table 36) and to what extent they experience a marriage formation by their mother (Table 37). In our description of entries into a marital family, we do not distinguish between those who enter it after one, or more, period(s) of cohabitation and those who enter it via the direct marriage of their mother. In some cases, union formation by a lone mother involves the father of the child but we have no information on whether this is the case. We just give a description of children's experiences of transformations of their families from a lone-parent family to a two-partner family (and a marriage, respectively). In these computations, we censor our observation if a child dies or if it stops living with its mother.

Births to lone women are relative uncommon both in Sweden and in Hungary. In addition, substantial fractions of these children experience a family-formation event after some amount of time so we are faced with data subsets that are to tiny for any extended analyses of these children's family-formation experiences. Consequently, we have to stop our observation at a relatively early stage in these groups of children's lives. Nevertheless, we can notice that the family-formation process of children born to lone women in Hungary appears to be faster than that of children born to lone women in Sweden.

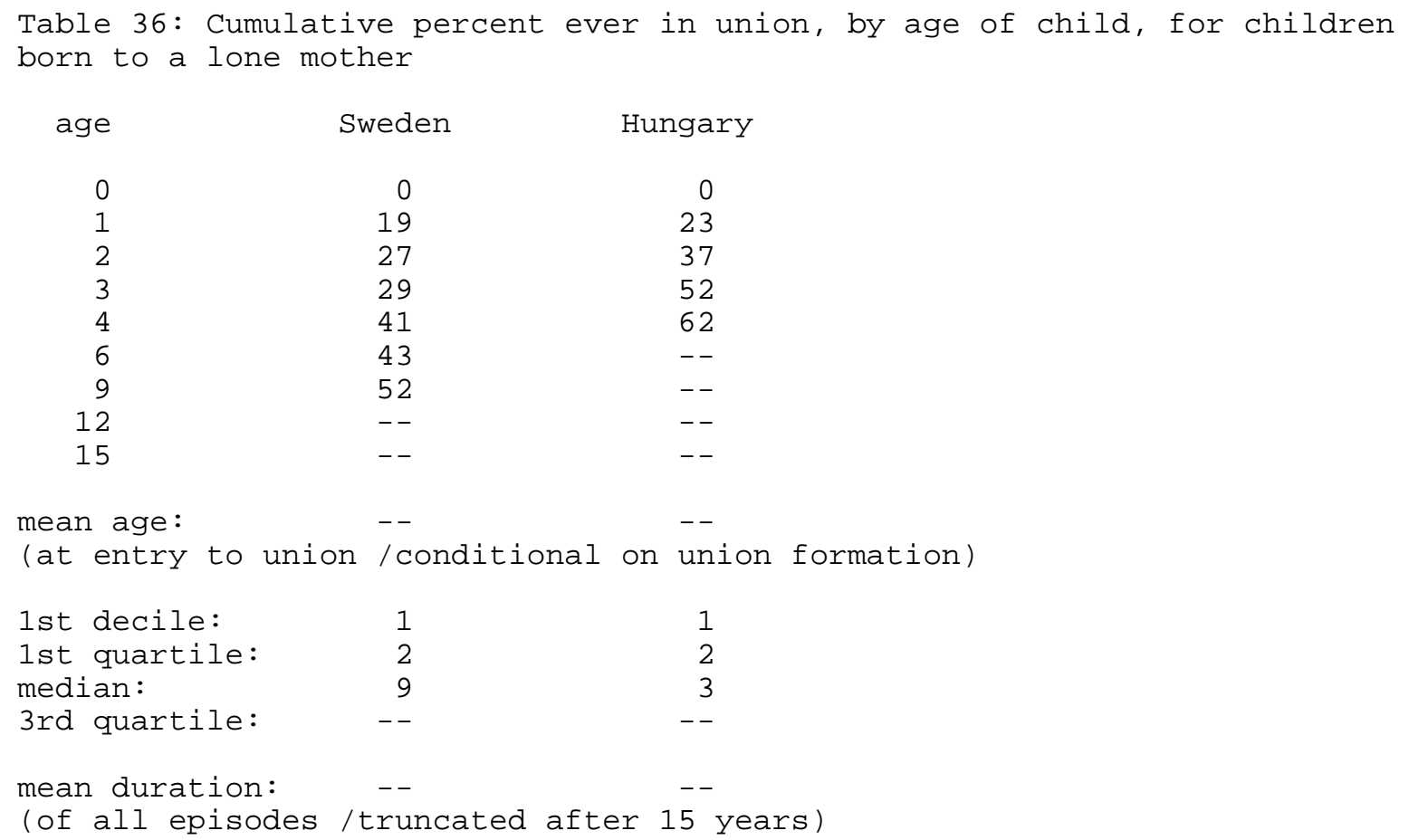


Table 37: Cumulative percent ever in marriage, by age of child, for children born to a lone mother

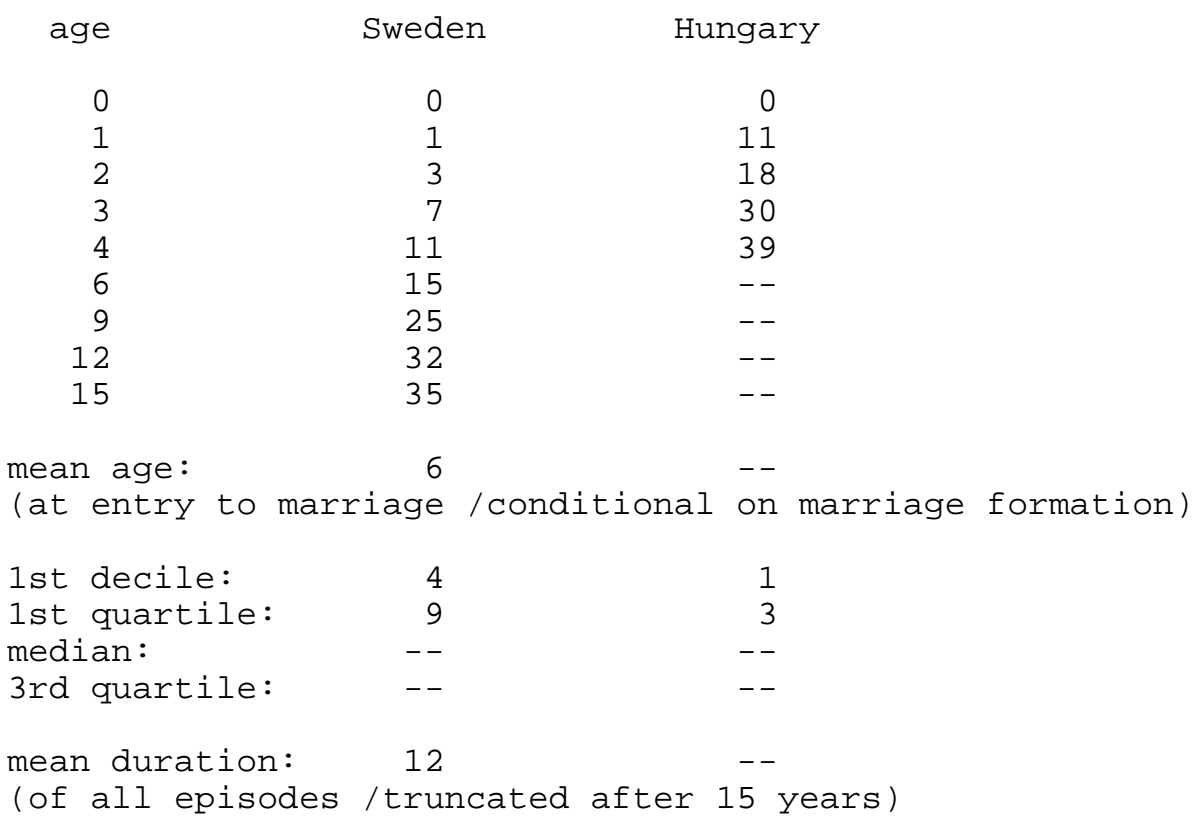

For children born into a consensual union, we can estimate these children's experiences of marriage formation in a similar way. Consequently, in Table 38, we present the cumulative percent of these children who ever experience a marriage of their mother, no matter whether this occurs in the original union, with the father, or in any other later union.

Table 38: Cumulative percent ever in marriage, by age of child, for children born in a consensual union

$\begin{array}{ccc}\text { age } & \text { Sweden } & \text { Hungary } \\ 0 & 0 & 0 \\ 1 & 17 & 11 \\ 2 & 27 & 18 \\ 3 & 38 & 22 \\ 4 & 45 & 25 \\ 6 & 56 & 36 \\ 9 & 68 & 49 \\ 12 & 76 & -- \\ 15 & 81 & -- \\ & & \\ \text { mean age: } & 5 & -- \\ \text { (at entry to marriage } & & \\ & 1 & 1 \\ \text { 1st decile: } & 2 & 4 \\ \text { 1st quartile: } & 5 & -- \\ \text { median: } & 12 & -- \\ \text { 3rd quartile: } & & \\ \text { mean duration: } & 7 & 15\end{array}$


The table demonstrates that marriage formation actually is very common in Swedish child families: eventually, around 80 percent of Swedish children from a consensual union will at some point in time have lived in a marital family. In Hungary, on the other hand, this process appears to take place at a much slower pace. Again, this might reflect that non-marital unions in that country are not as common as in Sweden and that they mainly occur to a selected group of people, with a behavior of relative family instability.

We conclude this sub-section with Table 39, which presents the cumulative percent who ever enter a marital family, based on all children born out of wedlock. In this presentation, we merge children born to a lone woman with those born to a cohabiting woman into one single category. Since the mixture of that category may be very different in different countries, we want to make the reader aware that it might be difficult to interpret differences in such marriage patterns between various countries. In the case of Sweden, and to some extent also for Hungary, the patterns of this table very much resemble those of Table 38, since most children who are born out of wedlock here are born in a consensual union. Again, we have censored our observations when a child dies and when it stops living with its mother but not when it experiences a union dissolution of the mother.

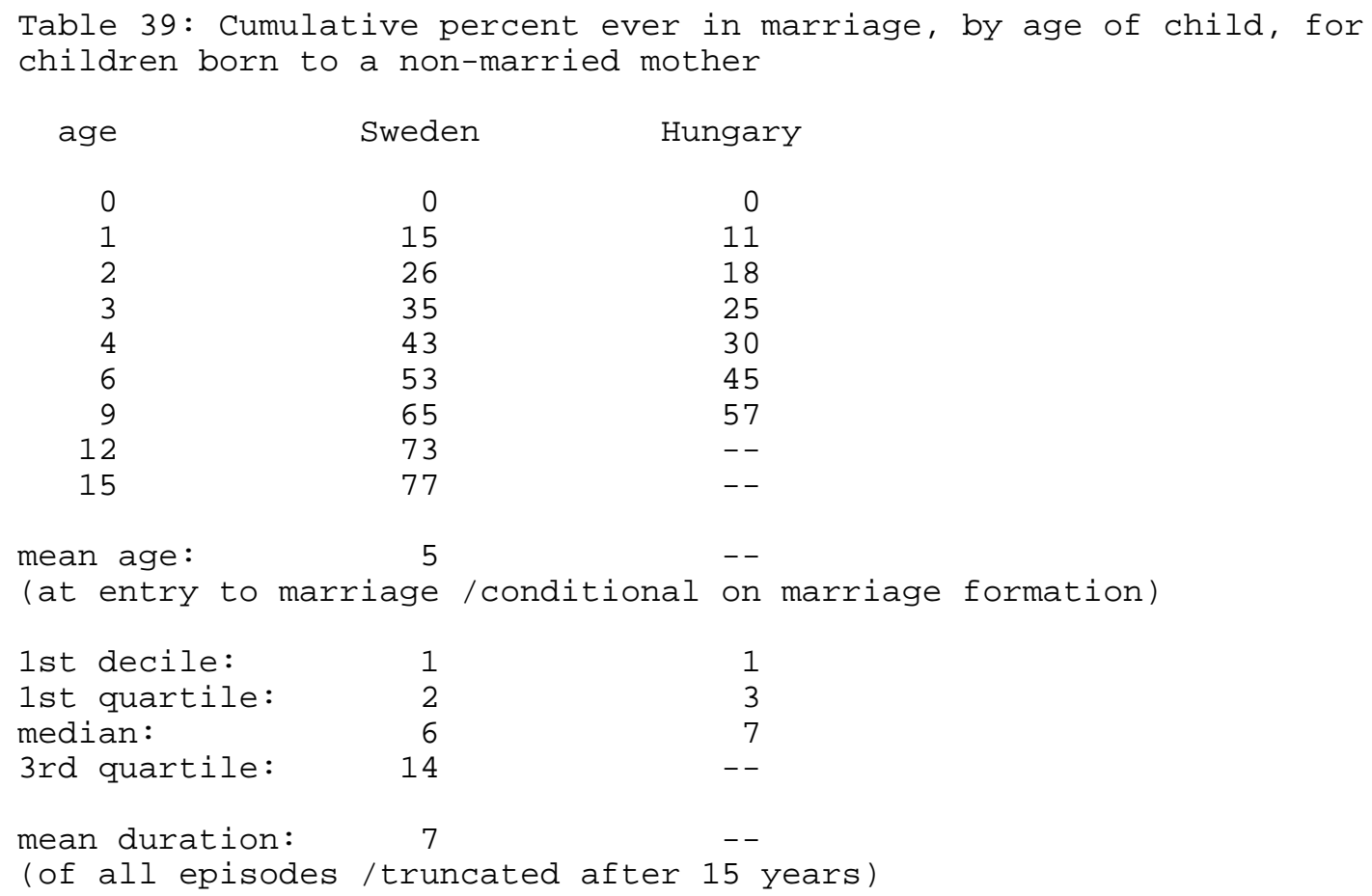




\section{2c. A competing-risks model of family transformation for children born in a consensual union}

As in our presentation of male and female cohabitants' experiences in their unions, we can estimate a competing-risks model for the experiences of children born in consensual unions. We then follow them until they exit from the state of being in a family with two cohabiting parents - either through the event of a family dissolution of some kind (Table 41) or through the transformation of the parental union into a formal marriage (Table 40). The sum of these two tables then present the cumulative percent of such children who will ever exit from the consensual-union status of their family of origin (Table 42).

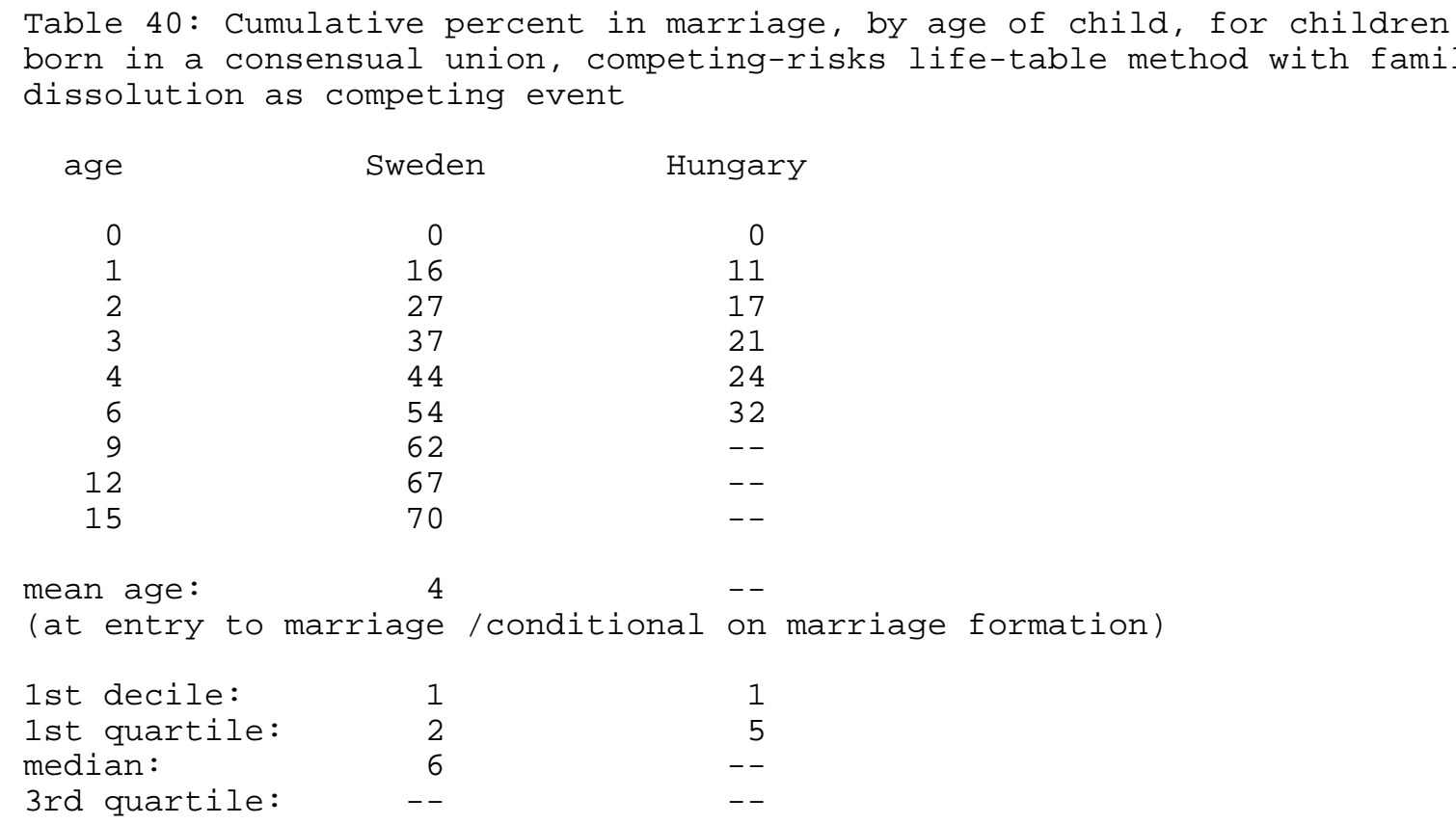

$\begin{array}{ccc}\text { age } & \text { Sweden } & \text { Hungary } \\ 0 & 0 & 0 \\ 1 & 16 & 11 \\ 2 & 27 & 17 \\ 3 & 37 & 21 \\ 4 & 44 & 24 \\ 6 & 54 & 32 \\ 9 & 62 & -- \\ 12 & 67 & -- \\ 15 & 70 & -- \\ & & \\ \text { mean age: } & 4 & -- \\ \text { (at entry to marriage } & & \\ & 1 & 1 \\ \text { 1st decile: } & 2 & 5 \\ \text { 1st quartile: } & 6 & -- \\ \text { median: } & -- & \end{array}$

Table 41: Cumulative percent out of union, by age of child, for children born in a consensual union, competing-risks life-table method with marriage formation of parents as competing event

$\begin{array}{ccc}\text { age } & \text { Sweden } & \text { Hungary } \\ 0 & 0 & 0 \\ 1 & 4 & 7 \\ 2 & 8 & 11 \\ 3 & 11 & 16 \\ 4 & 14 & 24 \\ 6 & 19 & 39 \\ 9 & 20 & -- \\ 12 & 21 & -- \\ 15 & 22 & -- \\ & & -- \\ \text { mean age: } & 4 & \\ \text { (at union disruption } & & \\ & & 2 \\ \text { 1st decile: } & 3 & 5 \\ \text { 1st quartile: } & -- & -- \\ \text { median: } & -- & -- \\ \text { 3rd quartile: } & -- & \end{array}$




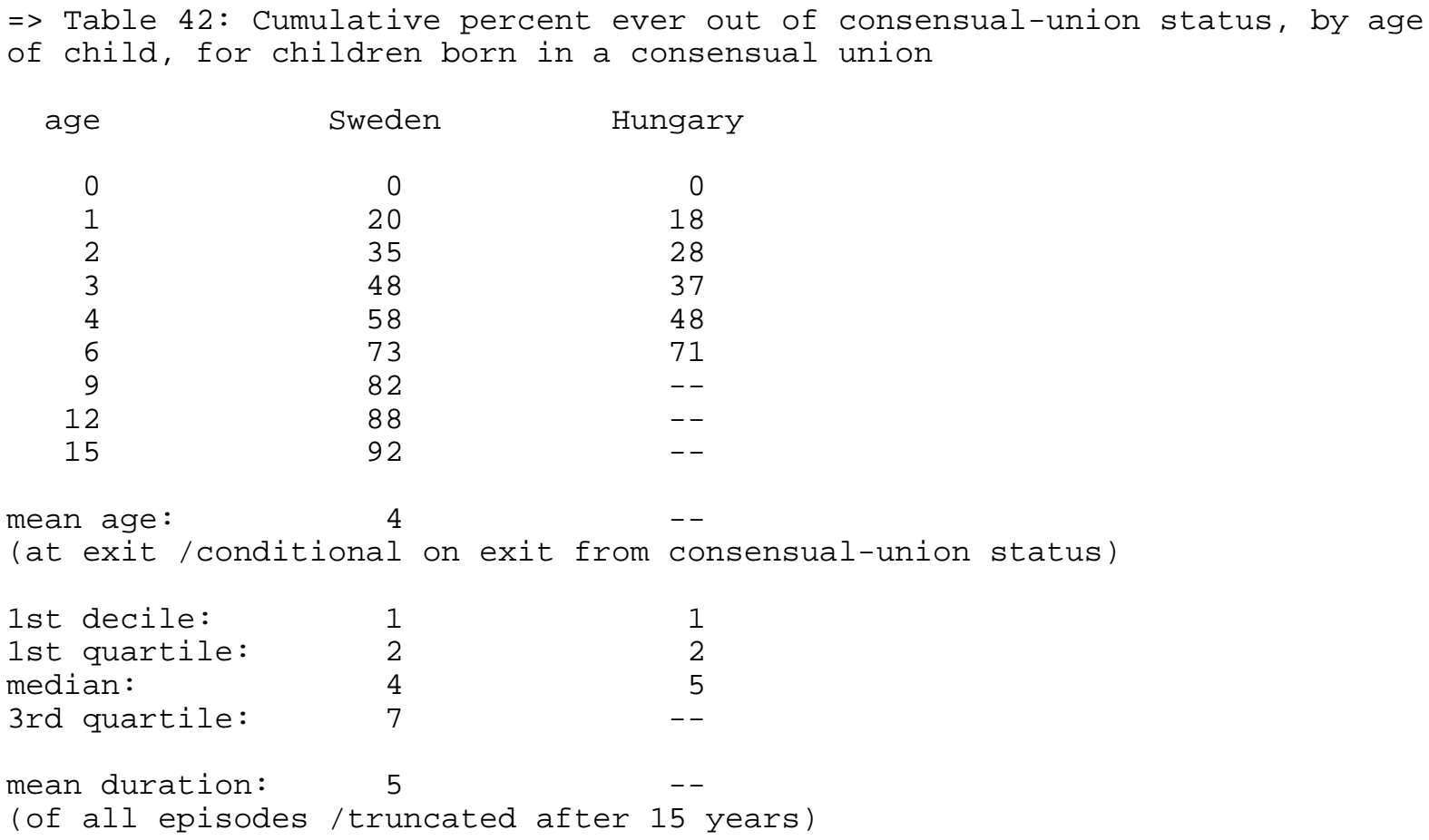

These tables once again demonstrate the very transitional character of the consensual unions in the two countries. In Hungary, about equal fractions of children born in a consensual union will end up in family dissolution and in marriage formation but the number of observations here is to small to allow to follow them beyond pre-school ages. In Sweden, around three times as many children of that kind will leave the consensual-union status of their original family through a marriage formation than through a union dissolution and only a few percent of them still remain in such a family status when they reach age 15 . 


\section{2d. Children's experiences of family re-formation}

For children who experience a family dissolution, we can calculate the same type of measures of family formation as we did for children born to a lone woman, i.e., measures of to what extent these children enter a union of any kind (Table 43) or a marriage (Table 44). However, in the resulting life tables of family re-formation, we use a different time variable than in our previous models. In the present situation, we follow children by time since their experience of the union disruption while we previously followed them by their age. Here we report on children's experiences after a disruption of their original union of birth and we present cumulative fractions who again enter any type of union and who enter a marital family (of their mother and any adult partner). We censor at a child's death, at its departure from its mother, and at its $15^{\text {th }}$ birthday. We follow children during the first 10 years after the experience of a family disruption of the original family.

The two tables demonstrate that a majority of children who experience a union dissolution of their mother also will experience the formation of another union of hers. Around one third will also experience a marriage formation of their mother. The family re-formation process occurs at a somewhat faster pace in Hungary than in Sweden.

In addition, it is possible to combine the family-formation experiences of children born to a lone woman with those of children experiencing a union disruption, in order to make one common model of family formation (of children to lone women). However, we refrain from such an exercise since the basic time variable is completely different in the two situations. Differences in the composition among children in different countries also make a crosscountry comparison very difficult.

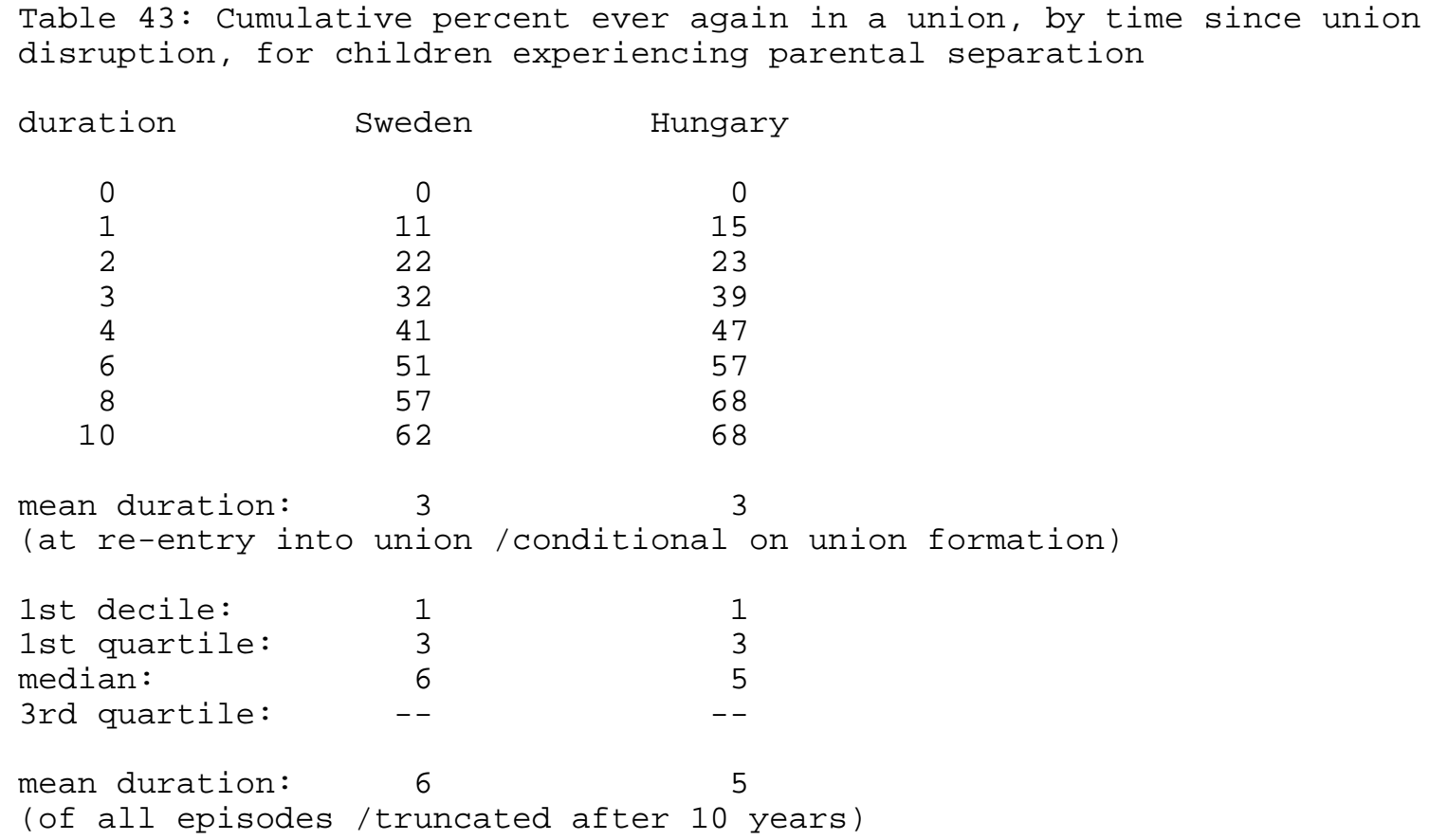


Table 44: Cumulative percent ever in marriage, by time since union disruption, for children experiencing parental separation

$\begin{array}{lcc}\text { duration } & \text { Sweden } & \text { Hungary } \\ 0 & 0 & 0 \\ 1 & 0 & 3 \\ 2 & 3 & 5 \\ 3 & 6 & 11 \\ 4 & 11 & 18 \\ 6 & 19 & 28 \\ 8 & 30 & 34 \\ 10 & 39 & 38 \\ & & \\ \text { mean duration: } & 6 & 5 \\ \text { (at entry to marriage /conditional on marriage formation) } \\ \text { 1st decile: } & 4 & 3 \\ \text { 1st quartile: } & 7 & 6 \\ \text { median: } & -- & -- \\ \text { 3rd quartile: } & -- & -- \\ \text { mean duration: } & 8 & 8 \\ \text { (of all episodes /truncated after } & 10 \text { years) }\end{array}$




\section{2e. Summary measures of children's family experiences}

We conclude our presentation of children's family experiences with a number of estimates of the proportion of time that children in Sweden and Hungary spend in various family types. These are calculated from the reports of their mothers on their various experiences during the calendar-year period we study. We present one table which gives such fractions when summed up over the entire childhood period (up to the $15^{\text {th }}$ birthday) and we present diagrams that display these fractions at each single age during childhood. We differentiate between time spent in the following family statuses:

- time with a lone mother without ever having been in a union,

- time after the child left its mother (in order to live with the father or somewhere else),

- time with a lone mother following union disruption,

- time in the consensual union where the child was born,

- time in marriage in the union where the child was born, and,

- time in a union formed with another partner, i.e., in a step family ${ }^{4}$.

Table 45 reveals that, on the average, children in Sweden spend more time with a lone mother than do children in Hungary. Still, 81 percent of all childhood time in Sweden is spent in a family with the two biological parents and almost two thirds of all time is spent in a marital family with the two parents.

$\begin{array}{lcc}\text { Table 45: Percent of time spent in different family types at ages 0-14 } \\ \text { years } & \text { Sweden } & \text { Hungary } \\ & & \\ & & 1 \\ \text { time with lone mother, from birth } & 2 & 6 \\ \text { time with lone mother, after disruption } & 9 & 0 \\ \text { time after leaving mother } & 2 & 8 \\ \text { ==> time with lone/no parent } & 12 & 2 \\ \text { time with both parents in consensual union } & 17 & 86 \\ \text { time with both parents in marriage } & 64 & 87 \\ ==>\text { time with both parents } & 6 & 51\end{array}$

The last two diagrams show how these experiences are distributed over the different ages of the childhood period. They show, for example, that experiences of living in a family with the two parents in a consensual union mainly is concentrated to pre-school ages while experiences of living with a lone mother or in a stepfamily is more concentrated to higher childhood ages.

\footnotetext{
${ }^{4}$ The union is defined as a step-family union only if it is formed later than 9 months after the birth of the child. In other cases, we assume that the union is formed by the two parents.
} 
Distribution of Swedish children, by family type, ages $0-15$ years

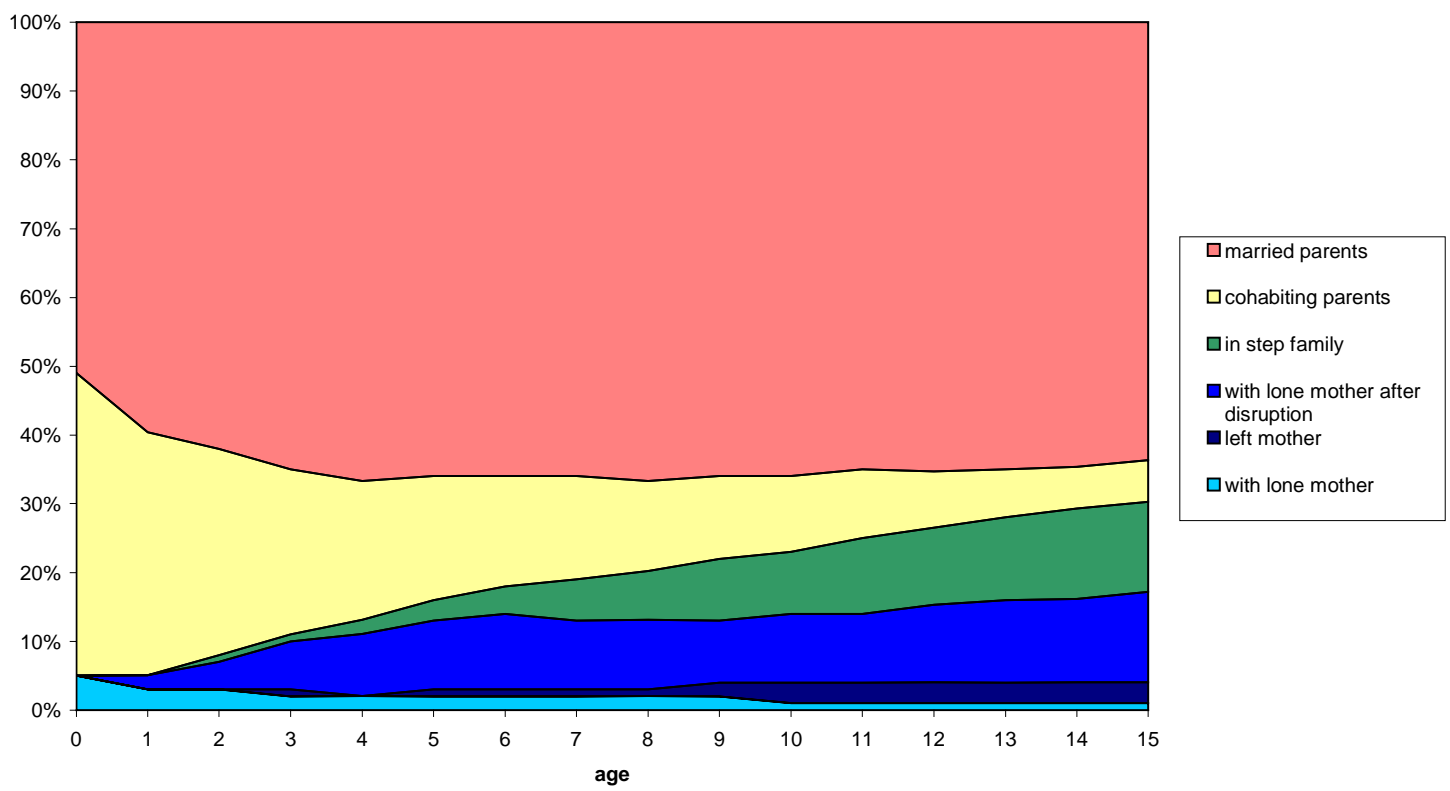

Distribution of Hungarian children, by family type, ages $0-15$ years

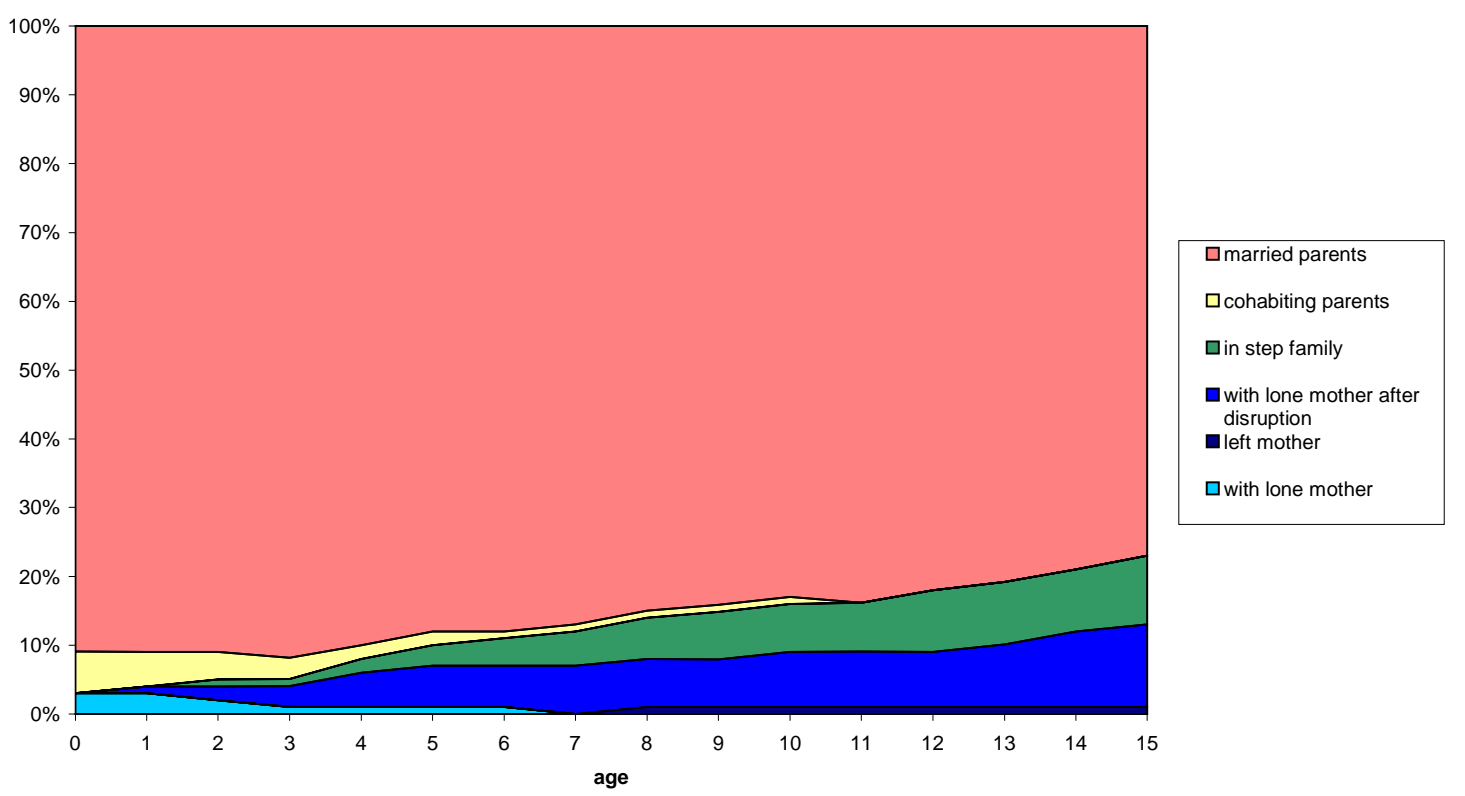




\section{OTHER POSSIBLE MEASURES...}

Evidently, it is possible to think of yet a few further measures to represent various aspects of family dynamics of men, women, and children, using life-table techniques such as those presented above. Some measures of that type have already been used in the existing demographic literature. We will here content ourselves to briefly mention a few ideas that others have thought of in one way or another:

- Time spent in parenthood can be described in more detail. King (1999) does so for the USA. She differentiates between time as a biological parent and time in social parenthood, and she accounts for actual living arrangements of parents and their children.

- Step-family experiences could perhaps be modeled in some detail, with separate models for men, women, and children, but our data sets are probably too tiny for an appropriate description of such matters.

- A better focus can be put on union order and birth order, for example in describing to what extent various demographic events occur in a first or in a later union and to what extent people experience a higher-order union. Kiernan (1999a,b) pay attention to matters of this kind.

\section{ACKNOWLEDGEMENTS}

We are grateful to Jan M. Hoem for valuable advice during the work with this project and to discussions with him, Larry Bumpass, Ron Lesthaeghe, and Kathleen Kiernan during a working meeting of this project in Brussels, the $27^{\text {th }}$ of May 2000. Many of the life-table measures we have used in our presentation were first suggested to us by Larry Bumpass. We also thank the Advisory Group of the FFS program of comparative research for its permission, granted under identification number 75, to use the Hungarian data for this study. In addition, we are grateful to the Stockholm University Demography Unit for its permission to use the cleaned version of the Swedish FFS.

\section{USEFUL LITERATURE AND REFERENCES}

Andersson, G., 1998. Giftermålsboom gav stabilare äktenskap. Välfärdsbulletinen, No. 4/1998: 26-27.

Bumpass, L., and Hsien-Hen Lu, 2000. Trends in cohabitation and implications for children's family contexts in the United States. Population Studies 54: 29-41.

Bumpass, L., and Raley, K., 1995. Redefining single-parent families: Cohabitation and changing family reality. Demography 32: 97-109.

Heuveline, P., and Timberlake, J., 2000. Towards a child-centered life course perspective on family structures: Multi-state early life tables using FFS data. Paper presented at the FFS Flagship Conference, Brussels, 29-31 May, 2000.

Hoem, J.M., 1991. To marry, just in case...: the Swedish widow's-pension reform and the peak in marriages in December 1989. Acta Sociologica 34:127-135. 
Kiernan, K, 1999a. Cohabitation in Western Europe. Population Trends, No. 96, pp. 25-32.

Kiernan, K, 1999b. Childbearing outside marriage in Western Europe. Population Trends, No. 98, pp. 11-20.

Kiernan, K, 2000. The state of European unions: An analysis of FFS data on partnership formation and dissolution. Paper presented at the FFS Flagship Conference, Brussels, 29-31 May, 2000.

King, R., 1999. Time spent in parenthood status among adults in the United States. Demography 36: 377-385.

Klijzing, E., and Macura, M., 1997. Cohabitation and extra-marital childbearing: Early FFS evidence. International Population Conference, Beijing, 11-17 October 1997, Vol 2, pp. 885901. IUSSP, Liège, Belgium.

Lesthaeghe, R., 2000. Fertility and partnership change: FFS contributions and requirements for the future. Paper presented at the FFS Flagship Conference, Brussels, 29-31 May, 2000.

Lesthaeghe, R., and Moors, G., 2000. Recent trends in fertility and household formation in the industrialized world. Interuniversity Papers in Demography, Interface Demography Department of Social Research, Vrije Universiteit Brussel.

Murphy, M., 2000. The evolution of cohabitation in Britain, 1960-95. Population Studies 54: 43-56.

Rohwer, G., and Trappe, H., 1997. Describing life courses. An illustration based on NLSY data. Paper presented at the POLIS Project Conference at the European University Institute, Florence, 28 February - 1 March, 1997.

Toulemon, L., and Lapierre-Adamcyk, É., 2000. Demographic patterns of motherhood and fatherhood in France. In Bledsoe, C., Lerner, S., and Guyer, J., eds., Fertility and the Male Life-Cycle in the Era of Fertility Decline. Oxford University Press. 